\title{
Sectorrapportage Hoger Pedagogisch Onderwijs
}

Citation for published version (APA):

Allen, J. P., Bertrand-Cloodt, D. A. M., \& Verhagen, A. M. C. (2013). Sectorrapportage Hoger

Pedagogisch Onderwijs. ROA. ROA Reports No. 003 https://doi.org/10.26481/umarep.2013003

Document status and date:

Published: 01/01/2013

DOI:

10.26481/umarep.2013003

Document Version:

Publisher's PDF, also known as Version of record

\section{Please check the document version of this publication:}

- A submitted manuscript is the version of the article upon submission and before peer-review. There can be important differences between the submitted version and the official published version of record.

People interested in the research are advised to contact the author for the final version of the publication, or visit the DOI to the publisher's website.

- The final author version and the galley proof are versions of the publication after peer review.

- The final published version features the final layout of the paper including the volume, issue and page numbers.

Link to publication

\footnotetext{
General rights rights.

- You may freely distribute the URL identifying the publication in the public portal. please follow below link for the End User Agreement:

www.umlib.nl/taverne-license

Take down policy

If you believe that this document breaches copyright please contact us at:

repository@maastrichtuniversity.nl

providing details and we will investigate your claim.
}

Copyright and moral rights for the publications made accessible in the public portal are retained by the authors and/or other copyright owners and it is a condition of accessing publications that users recognise and abide by the legal requirements associated with these

- Users may download and print one copy of any publication from the public portal for the purpose of private study or research.

- You may not further distribute the material or use it for any profit-making activity or commercial gain

If the publication is distributed under the terms of Article $25 \mathrm{fa}$ of the Dutch Copyright Act, indicated by the "Taverne" license above, 


\title{
Sectorrapportage Hoger Pedagogisch Onderwijs
}

\author{
Jim Allen \\ Daniëlle Bertrand-Cloodt \\ Annelore Verhagen
}

ROA-R-2013/3 


\section{Colofon}

(C) Researchcentrum voor Onderwijs en Arbeidsmarkt (ROA). Niets uit deze uitgave mag op enige manier worden verveelvoudigd zonder voorafgaande schriftelijke toestemming van de directeur van het ROA.

\section{Researchcentrum voor Onderwijs en Arbeidsmarkt}

School of Business and Economics

Maastricht University

\section{Vormgeving}

ROA secretariaat, Maastricht

\section{Verkoop}

Researchcentrum voor Onderwijs en Arbeidsmarkt email: secretary-roa-sbe@maastrichtuniversity.nl website: www.roa.nl

ISBN: 978-90-532I-508-I

februari 2013 


\section{Inhoud}

1 Inleiding 1

2 De arbeidsmarkt voor afgestudeerden van het HPO 5

3 Arbeidsmarktperspectieven $\quad 23$

4 Vereiste competenties voor afgestudeerden van het HPO 25

$\begin{array}{lll}4.1 & \text { Trends en ontwikkelingen } & 25\end{array}$

$\begin{array}{ll}4.2 \text { Vereist niveau competenties } & 27\end{array}$

$\begin{array}{lll}4.3 \text { Competentietekorten } & 30\end{array}$

5 Conclusie $\quad 35$

$\begin{array}{ll}\text { Literatuur } & 47\end{array}$

Bijlage: Kernindicatoren voor HPO Bachelor-opleidingen 49 



\section{Inleiding}

De HBO-Monitor vierde in 2010 haar 20-jarige bestaan. In de eerste twintig jaar van de $\mathrm{HBO}-$ Monitor is op verschillende manieren gerapporteerd over de aansluiting tussen het $\mathrm{HBO}$ en de arbeidsmarkt, over de vraag wat de $\mathrm{HBO}$-studenten tijdens hun studie hebben geleerd en over de vraag hoe zij de gevolgde opleiding beoordelen. Hierbij is vooral gericht gerapporteerd op landelijk niveau en op het niveau van de onderwijsinstelling. De tussenliggende laag, de afzonderlijke sectoren, (met uitzondering van de sector kunst), zijn daarbij (met uitzondering van het eerste jaar van de HBO-Monitor) zelden als insteek gebruikt. Afgezien van de sector Kunst, wordt voor de resterende zes sectoren: Economie, Gezondheidszorg, Landbouw, Pedagogisch, Sociaalagogisch en Techniek in het kader van het 20-jarige bestaan dan ook een rapport geschreven met hun sector als centraal ankerpunt. Vanuit dit perspectief is de voorliggende rapportage specifiek gericht op de HBO-sector Hoger Pedagogisch Onderwijs (HPO). Hierbij staan de implicaties van recente alsook toekomstige arbeidsmarktontwikkelingen in de sector op de gevraagde competenties van afgestudeerden centraal. Zo wordt achterhaald op welke competenties het onderwijsveld zich de komende jaren zou moeten richten om afgestudeerden optimaal voor te kunnen bereiden op hun beroepsloopbaan in de pedagogische sector.

De context van deze rapportage wordt gevormd door de strategische agenda $\mathrm{HO}$ en het hoofdlijnenakkoord tussen de HBO-raad en het Ministerie van Onderwijs, Cultuur en Wetenschap (Ministerie van OC\&W, 20II). Hierin worden afspraken gemaakt over het met een zekere regelmaat uitvoeren van sectorale verkenningen. De huidige rapportage in het kader van 20 jaar HBO-Monitor levert relevant materiaal voor die sectorale verkenningen.

\section{Leeswijzer}

Als uitgangspunt voor voorliggende sectorrapportage wordt in hoofdstuk I allereerst kort een algemeen beeld van deze sector geschetst. Vervolgens wordt in hoofdstuk 2 aan de hand van een breed scala aan indicatoren de arbeidsmarktsituatie voor recent afgestudeerden van het Hoger Pedagogisch Onderwijs beschreven. Hierna wordt in hoofdstuk 3 stilgestaan bij de verwachte arbeidsmarktperspectieven voor afgestudeerden van het HPO. Tot slot wordt in hoofdstuk 4 ingegaan op competenties die recent afgestudeerden van het HPO dienen te bezitten. Tot slot worden in hoofdstuk 
5 de belangrijkste conclusies samengevat. In de bijlage worden de resultaten voor enkele kernindicatoren uitgesplitst naar HPO Bachelor-opleidingen.

\section{HPO cijfermatig in beeld}

Het HPO - met zo'n 55.000 studenten in 2010 - heeft een aandeel van ruim $13 \%$ in het HBO (HBO-raad, 20I2). Tabel I.I geeft een overzicht van de tien bachelor opleidingen met het grootste aantal studenten binnen de pedagogische sector. De bachelor opleiding tot leraar basisonderwijs is veruit het meest populair, bijna $5 \mathrm{I} \%$ van de HPO bachelor studenten kiest in 20 IO voor deze opleiding. Daarnaast geldt dat in 2010 voor de bachelor opleidingen leraar voortgezet onderwijs $\mathrm{I}^{\mathrm{e}}$ graad in lichamelijke oefening, en $2^{\mathrm{e}}$ graad in Engels, geschiedenis en Nederlands elk meer dan 2.000 studenten kozen.

Tabel 1.1

De 10 grootste opleidingen binnen het Hoger Pedagogisch Onderwijs in 2010

\begin{tabular}{|l|l|r|}
\hline & Opleiding & Inschrijvingen \\
\hline 1 & b opleiding tot leraar basisonderwijs & 27.970 \\
\hline 2 & b opl. leraar vo 1e gr in lichamelijke oefening & 4.562 \\
\hline 3 & b opl. leraar vo 2e gr in Engels & 3.481 \\
\hline 4 & b opl. leraar vo 2e gr in geschiedenis & 2.872 \\
\hline 5 & b opl. leraar vo 2e gr in Nederlands & 2.068 \\
\hline 6 & b opl. leraar vo 2e gr in wiskunde & 1.921 \\
\hline 7 & b opl. leraar vo 2e gr in biologie & 1.238 \\
\hline 8 & b opl. leraar vo 2e gr in gezondheidszorg en welzijn & 1.156 \\
\hline 9 & b opl. leraar vo 2e gr in aardrijkskunde & 969 \\
\hline 10 & b opl. leraar vo 2e gr in algemene economie & 866 \\
\hline & HPO totaal & 55.002 \\
\hline
\end{tabular}

Bron: HBO-raad (2012)/bewerking ROA.

Tabel I. 2 bevat een aantal achtergrondkenmerken van de afgestudeerden van de HBO sector onderwijs. Ter vergelijking worden ook de cijfers voor het $\mathrm{HBO}$ als geheel gepresenteerd. In termen van leeftijd en hoogst voltooide vooropleiding wijken HPO'ers niet veel af van het $\mathrm{HBO}$ als geheel. Wel zijn ze iets vaker op basis van een $\mathrm{HAVO}$ of $\mathrm{HBO}$ vooropleiding aan hun $\mathrm{HPO}$-opleiding begonnen. Het aandeel vrouwen, allochtonen en doorstroming naar een vervolgopleiding wijkt wel af van het $\mathrm{HBO}$ gemiddelde. Het aandeel vrouwen ligt ver boven het $\mathrm{HBO}$-gemiddelde, het aandeel allochtonen - zowel westerse als niet-westerse - ligt juist lager, en ze zijn vaker na afronding van hun HPO-opleiding doorgestroomd naar een vervolgopleiding. 
Tabel 1.2

Achtergrondkenmerken van recent afgestudeerden van het HPO, 2006-2010

\begin{tabular}{|l|r|r|}
\hline & HPO & HBO totaal \\
\hline Vrouw (\%) & $79,9 \%$ & $55,9 \%$ \\
\hline Leeftijd (gem.) & 25,32 & 25,18 \\
\hline Allochtoon (\%) & & \\
\hline Westerse & $3,6 \%$ & $7,2 \%$ \\
\hline Niet-westerse & $3,4 \%$ & $6,2 \%$ \\
\hline Hoogst voltooide vooropleiding (\%) & & \\
\hline HAVO & $53,9 \%$ & $48,8 \%$ \\
\hline VWO & $12,4 \%$ & $16,7 \%$ \\
\hline BOL/BBL/inservice & $24,5 \%$ & $26,8 \%$ \\
\hline HBO & $7,7 \%$ & $5,3 \%$ \\
\hline andere vooropleiding & $1,5 \%$ & $2,3 \%$ \\
\hline Vervolgopleiding gevolgd (\%) & $31,0 \%$ & $22,1 \%$ \\
\hline
\end{tabular}

Bron: HBO-Monitor 2006-2010

Tabel I.3 geeft de populairste branches weer voor recent afgestudeerden van het HPO. De data zijn afkomstig van de HBO-Monitor. De cijfers hebben betrekking op de periode 2006-20I0 en geven de branches weer waarin de grootste groepen voormalige HPO'ers werkzaam zijn op het enquêtemoment (circa I, 5 jaar na afstuderen).

Tabel 1.3

Aandeel werkende recent afgestudeerden van het HPO per branche, 2006-2010 (\%)

\begin{tabular}{|l|l|r|r|}
\hline & Branche: & $\%$ HPO & $\%$ HBO totaal \\
\hline 1 & Onderwijs & 89,1 & 17,4 \\
\hline 2 & Maatschappelijke dienstverlening zonder overnachting & 2,8 & 5,0 \\
\hline 3 & Openbaar bestuur, overheidsdiensten en verplichte sociale verzekeringen & 1,6 & 4,8 \\
\hline 4 & Sport en recreatie & 0,8 & 0,9 \\
\hline 6 & Detailhandel (niet in auto's) & 0,7 & 2,5 \\
\hline 7 & Gezondheidszorg & 0,6 & 11,0 \\
\hline 8 & Arpleging, verzorging en begeleiding met overnachting & 0,6 & 4,3 \\
\hline
\end{tabular}

Bron: HBO-Monitor 2006-2010

In de periode 2006-20I0 waren er in totaal bijna 25.800 recent afgestudeerden HBO'ers met een pedagogische opleiding die betaald werk hadden. Zoals verwacht was de overgrote meerderheid van deze groep (89\%) werkzaam in het onderwijs. Dit komt overeen met 22.975 werkende personen. In de overige branches is minder dan drie procent van het totaal aantal afgestudeerden HPO werkzaam, wat betekent dat de branches waar de overige afgestudeerden werkzaam zijn, erg divers zijn. In 'maatschappelijke dienstverlening zonder overnachting' is $2,8 \%$ van de HPO afgestudeerden werkzaam, terwijl dat bij 'openbaar bestuur, overheidsdiensten en verplichte sociale verzekeringen' $\mathrm{I}, 6 \%$ is. Voor de overige branches is het aandeel zelfs minder dan één procent. 
Tevens is voor de deze periode (2006-20IO) gekeken in welke branches afgestudeerden van het HPO de dominante groep zijn. Gemiddeld heeft ruim een zevende van het totaal aantal afgestudeerde HBO'ers een pedagogische achtergrond (I $5,3 \%)$. Tabel I.4 geeft de branches weer met het hoogste aandeel afgestudeerden van het HPO. Branches waar het aandeel HPO'ers lager is dan van andere sectoren zijn niet weergegeven.

\section{Tabel 1.4}

Branches waar afgestudeerden van het HPO de dominante groep zijn onder HBO-afgestudeerden, 2006-2010 (\%)

\begin{tabular}{|c|l|r|}
\hline & Branche: & HPO\% \\
\hline 1 & Primair en speciaal onderwijs & 96,3 \\
\hline 2 & Onderwijs & 71,2 \\
\hline 3 & Voortgezet onderwijs & 70,9 \\
\hline $\begin{array}{l}\text { Bron: HBO-Monitor 2006-2010 } \\
\text { Opmerking: Alleen branches waarbinnen ten minste 100 HBO-afgestudeerden werkzaam zijn worden weergegeven. }\end{array}$
\end{tabular}

Afgestudeerden van het HPO zijn in slechts drie branches de dominante groep. Dit in tegenstelling tot bijvoorbeeld $\mathrm{HBO}$ opleidingen in de sector economie; personen met een economische opleidingsachtergrond in het $\mathrm{HBO}$ werken vrijwel in elke branche. Toch hebben in het primair en speciaal onderwijs bijna alle HBO'ers een pedagogische achtergrond (96\%), en ook in de branches Onderwijs en Voortgezet onderwijs is ruim $70 \%$ van de $\mathrm{HBO}$ 'ers afkomstig uit het $\mathrm{HPO}$.

Tabel I.5 geeft de belangrijkste beroepen aan voor recent afgestudeerden van het HPO tussen 2006 en 20I0. Verreweg de grootste beroepsgroep is die van 'leraar basisonderwijs' met een aandeel van $66,9 \%$. Een tamelijk grote groep HPO-afgestudeerden komt terecht in vergelijkbare functies op $\mathrm{HBO}$ niveau: 'docenten sociale vakken $\left(2^{\mathrm{e}}\right.$ en $3^{\mathrm{e}} \mathrm{gr}$.)' en 'docenten talen en expressie'.

\section{Tabel 1.5}

Aandeel werkende recent afgestudeerden van het HPO per beroep, 2006-2010 (\%)

\begin{tabular}{|c|c|c|c|}
\hline & Beroep: & $\% \mathrm{HPO}$ & $\%$ HBO totaal \\
\hline 1 & Leraar basisonderwijs & 66,9 & 10,4 \\
\hline 2 & Docenten sociale vakken ( $2^{\mathrm{e}}$ en $3^{\mathrm{e}} \mathrm{gr}$.) & 7,3 & 1,2 \\
\hline 3 & Docenten talen en expressie & 6,4 & 2,0 \\
\hline 4 & Onderwijskundig medewerkers & 2,0 & 0,9 \\
\hline 5 & Verzorgend personeel & 1,9 & 1,8 \\
\hline 6 & Docenten sociale vakken ( $1^{\mathrm{e}} \mathrm{gr}$. en W0) & 1,9 & 0,3 \\
\hline 7 & Sociaal-cultureel werkers & 1,4 & 8,9 \\
\hline 8 & Docenten economisch-administratieve vakken ( $2^{\mathrm{e}}$ en $3^{\mathrm{e}} \mathrm{gr}$.) & 1,2 & 0,3 \\
\hline
\end{tabular}

Bron: HBO-Monitor 2006-2010 


\section{De arbeidsmarkt voor afgestudeerden van het HPO}

In hoofdstuk 2 staat de arbeidsmarktintrede van recent afgestudeerden van het Hoger Pedagogisch Onderwijs centraal. In dit hoofdstuk komen verschillende indicatoren aan bod die een indicatie geven over de transitie van het Hoger Economisch Onderwijs naar de arbeidsmarkt over de periode 1998-20I0. Zodoende wordt een beeld verschaft van niet alleen de huidige situatie voor afgestudeerden van het HPO op de arbeidsmarkt, maar ook van de mate waarin die situatie stabiel is, structureel beter of slechter wordt, of gevoelig is voor de conjunctuur. De indicatoren die achtereenvolgens aan bod komen zijn het werkloosheidspercentage, de zoekduur tot de eerste baan, tijdelijke aanstellingen, deeltijdwerkers, het niveau en de richting van de huidige functie, het percentage dat de aansluiting tussen onderwijs en arbeidsmarkt als voldoende of goed betiteld, het bruto uurloon, de tevredenheid met de huidige baan, het percentage dat spijt heeft van de gevolgde opleiding, het percentage dat een cursus of bedrijfsopleiding gevolgd heeft, het percentage dat contact heeft met de hogeschool in verband met bijscholing en tot slot het oordeel over de breedte en diepgang van de gevolgde opleiding. Voor elke indicator wordt de trend voor de recent afgestudeerden van het Hoger Pedagogisch Onderwijs afgezet tegen de trend van de totale groep recent afgestudeerde HBO'ers. De data hebben betrekking op de periode 1998-20IO. Het gaat hierbij om cijfers over het totale Hoger Pedagogisch Onderwijs, wat betekent dat de resultaten voor de specifieke onderliggende opleidingstypen hiervan af kunnen wijken. ${ }^{\mathrm{I}}$ In de bijlage zijn voor de periode 2006-20IO de kernindicatoren werkloosheid, werkzaam in kerndomein, inkomen huidige baan, spijt van de gekozen opleiding en tevredenheid met huidige baan weergegeven voor de afzonderlijke Bachelor-opleidingen van het Hoger Pedagogisch Onderwijs. Deze cijfers worden afgezet tegen het $\mathrm{HPO}$-gemiddelde en het HBO-gemiddelde.

\section{Werkloosheid}

Afgestudeerden van het HPO lijken I, 5 jaar na het behalen van het diploma minder last te hebben van de conjunctuur dan andere HBO'ers. Zowel afgestudeerden van het $\mathrm{HPO}$ als de totale groep afgestudeerden van het $\mathrm{HBO}$ hadden het moeilijker als gevolg van de economische crisis (de werkloosheid steeg), maar figuur 2.I laat zien dat afgestudeerden van het HPO het beduidend minder moeilijk hadden. Dit blijkt uit

I. Voor meer gedetailleerde informatie op het niveau van afzonderlijke opleidingen over recent afgestudeerden van het Hoger Economisch Onderwijs wordt verwezen naar de HBO-Monitor Kerncijfers Online. Deze informatie is te vinden op www.roa.unimaas.nl/kerncijfers.htm. 
het relatief lage werkloosheid onder HPO afgestudeerden ten opzichte van het HBO gemiddelde in de periode 2003-2005 (laagconjunctuur) en tijdens de recente economische crisis (sinds 2008). Het minimale verschil in werkloosheidspercentages tussen het $\mathrm{HPO}$ en $\mathrm{HBO}$-gemiddelde in de periodes waarin het economisch wat beter gaat (met in 2006 zelfs een piek boven het gemiddelde) lijkt erop te wijzen dat wanneer de huidige economische crisis voorbij is, de onder $\mathrm{HPO}$ afgestudeerden weer net zo hoog zal zijn als het $\mathrm{HBO}$-gemiddelde, en misschien zelfs iets hoger. Zie de bijlage voor de werkloosheidspercentages voor de HPO Bachelor-opleidingen.

Figuur 2.1

Ontwikkeling werkloosheidspercentage op enquêtemoment, 1998-2010

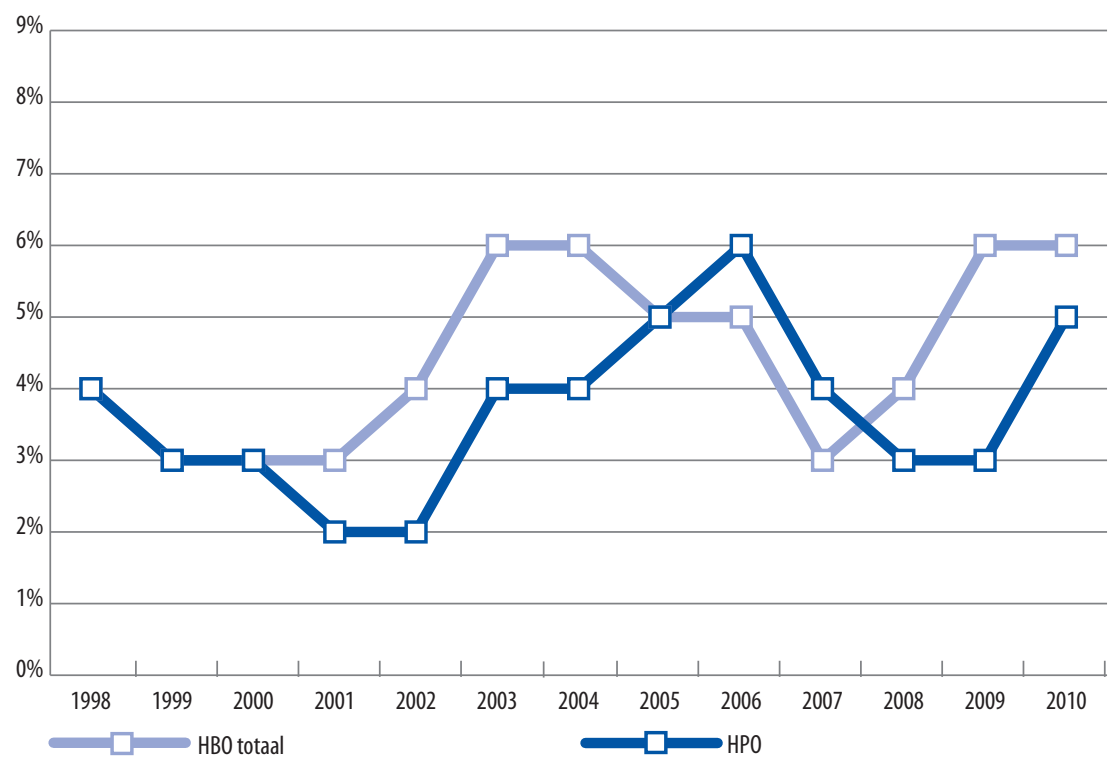

Bron: HBO-Monitor 1998-2010.

\section{Zoekduur tot eerste baan}

Figuur 2.2 geeft weer hoeveel maanden HPO-afgestudeerden werkloos waren voordat ze begonnen aan hun eerste baan. Deze figuur laat wederom zien dat afgestudeerden van het HPO minder last lijken te hebben van de conjunctuur dan andere HBO'ers. Gemiddeld genomen over de hele periode vinden HPO-afgestudeerden eerder een baan dan hun studiegenoten van het HBO. HPO'ers doen er gemiddeld is dagen ( 0,62 maanden) over voordat ze beginnen aan hun eerste baan tegenover 26 dagen (o,84 maanden) bij de totale groep HBO-afgestudeerden. De figuur laat zien dat HPO'ers ondanks de hogere werkloosheid als gevolg van de crisis, sneller hun eerste 
baan vinden, hetgeen wordt weergegeven door het dalend verloop van de curve. Voor het $\mathrm{HBO}$ als geheel is de zoekduur gestegen als gevolg van de economische crisis.

Figuur 2.2

Maanden werkloos voor begin eerste baan, 1999-2010²

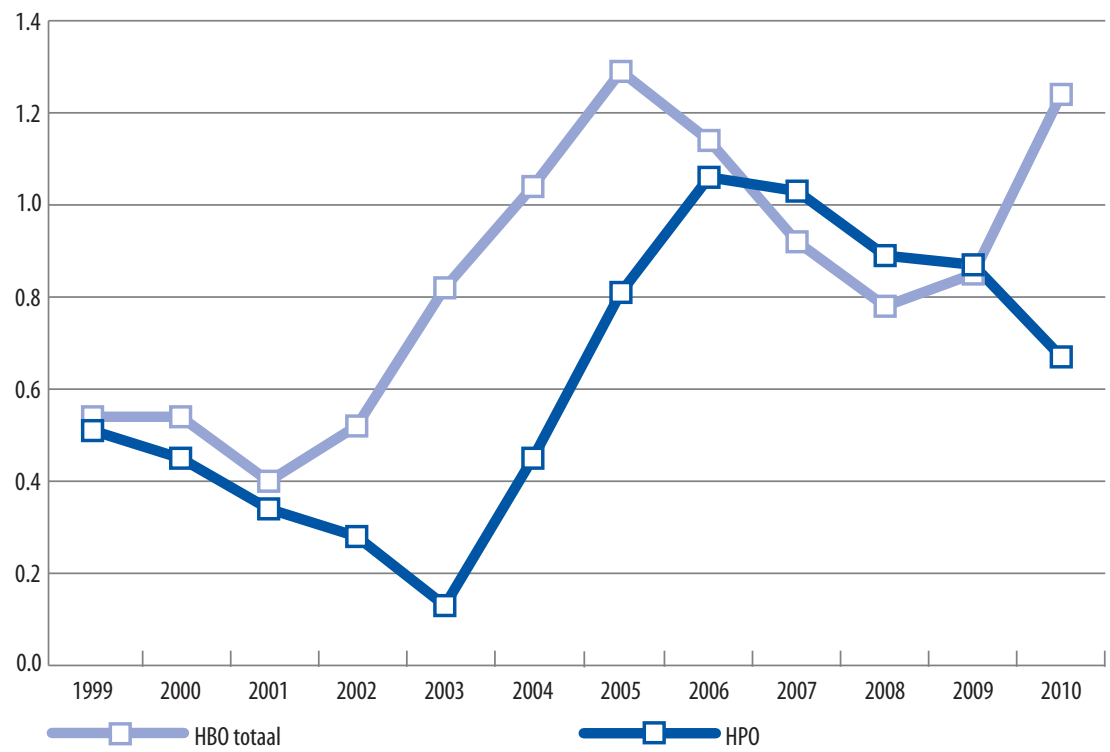

Bron: HBO-Monitor 1999-2010

\section{Tijdelijke aanstelling}

Hoewel het percentage tijdelijke contracten sterk afhankelijk is van de conjuncturele situatie, laat figuur 2.3 zien dat dit percentage sinds 1998 ook structureel is toegenomen. Dit geldt zowel voor het HPO als het HBO-gemiddelde. Toch lag het percentage tijdelijke contracten bij afgestudeerden van het HPO tussen $200 \mathrm{I}$ en 2005 beduidend lager dan het $\mathrm{HBO}$ gemiddelde. Vanaf 2004 is er echter sprake van een inhaalslag aan tijdelijke aanstellingen onder HPO'ers, en vanaf 2006 ligt het zelfs boven het gemiddelde waarna het percentage zich lijkt te hebben gestabiliseerd.

2. De variabele Werkloosheid tot eerste baan is niet beschikbaar voor het meetjaar 1998 . 
Figuur 2.3

Trend tijdelijke aanstelling (\%), 1998-2010

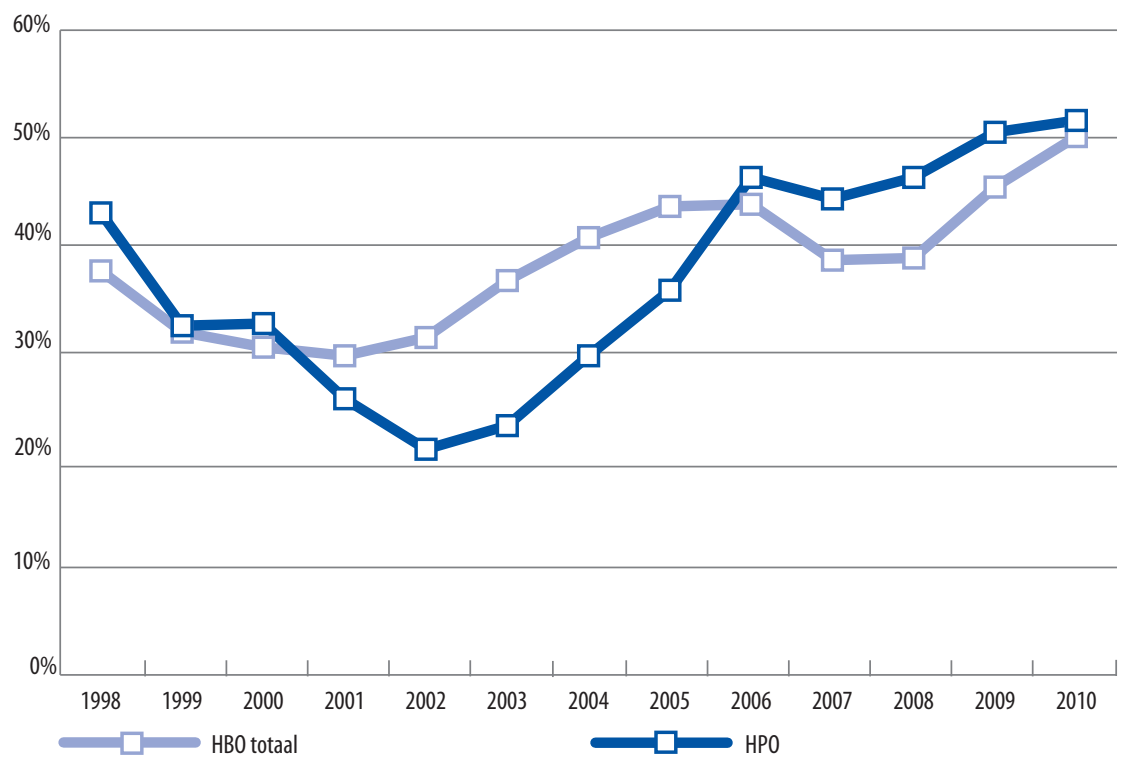

Bron: HBO-Monitor 1998-2010

\section{Parttime werk}

Figuur 2.4 laat zien dat recent afgestudeerden van het HPO verhoudingsgewijs vaker parttime werken, en dus minder vaak fulltime dan het HBO-gemiddelde. Onder fulltime wordt verstaan dat zij een baan hebben van meer dan 32 uur per week. Het percentage dat parttime werkt neemt sinds 1998 structureel toe, zowel voor de sector onderwijs als voor het $\mathrm{HBO}$ als geheel. Ook hier is naast de algemene trend een effect van de conjunctuur duidelijk zichtbaar, hoewel het conjunctuureffect bij HPO met een of twee jaar vertraging lijkt op te treden. Dat zou betekenen dat de onderwijssector wat betreft het aandeel parttime aanstellingen later dan gemiddeld in speelt/hoeft te spelen op conjunctuurschommelingen. Het is daarom mogelijk dat het aandeel parttimers onder HPO afgestudeerden de komende twee, drie jaar sterker zal gaan toenemen (ook als het tegen die tijd beter gaat met de economie), omdat dan pas het conjunctuureffect van de recente crisis terug te zien is in de percentages parttimers. 
Figuur 2.4

Trend parttime werk (\%), 1998-2010

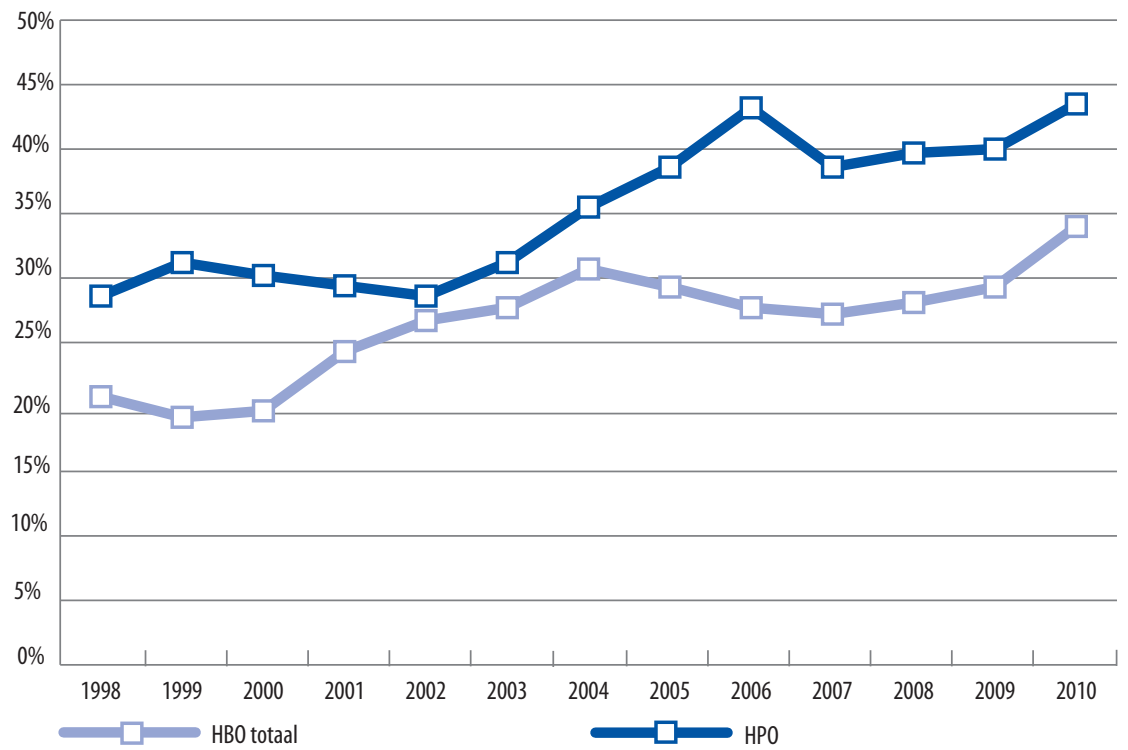

Bron: HBO-Monitor 1998-2010

\section{Niveau en richting huidige functie}

Door verdringingseffecten op de arbeidsmarkt is het mogelijk dat recent afgestudeerden noodgedwongen genoegen moeten nemen met een functie die onder hun niveau is of die buiten hun vakgebied is. In vergelijking met de totale groep $\mathrm{HBO}$-afgestudeerden werken $\mathrm{HPO}$-afgestudeerden minder vaak onder hun niveau. De aandelen zijn respectievelijk 7\% voor $\mathrm{HPO}$ en $17,5 \%$ voor $\mathrm{HBO}$ als geheel. Het verschil tussen $\mathrm{HPO}$ en $\mathrm{HBO}$ is nog groter wat betreft het aandeel dat een baan heeft buiten hun eigen vakrichting. Starters op de arbeidsmarkt met een diploma $\mathrm{HBO}$ onderwijs werken aanzienlijk minder vaak buiten hun richting dan andere afgestudeerde HBO'ers. Van eerstgenoemden geeft 6,4\% aan dat hun werkgever geen specifieke of een andere opleidingsrichting voor de huidige functie vereist, terwijl dit gemiddeld $19,2 \%$ is onder starters met een $\mathrm{HBO}$-opleiding.

Wanneer opleidingsniveau en -richting gecombineerd worden, kan achterhaald worden of de recent afgestudeerden binnen hun kerndomein terechtkomen. Met een baan binnen het kerndomein wordt bedoeld dat de afgestudeerden er in slagen een baan te vinden op minimaal het eigen opleidingsniveau, in dit geval HBO, alsook in dezelfde richting als de voltooide opleiding. 


\section{Figuur 2.5}

Vereist niveau en vereiste richting van de baan, 2006-2010

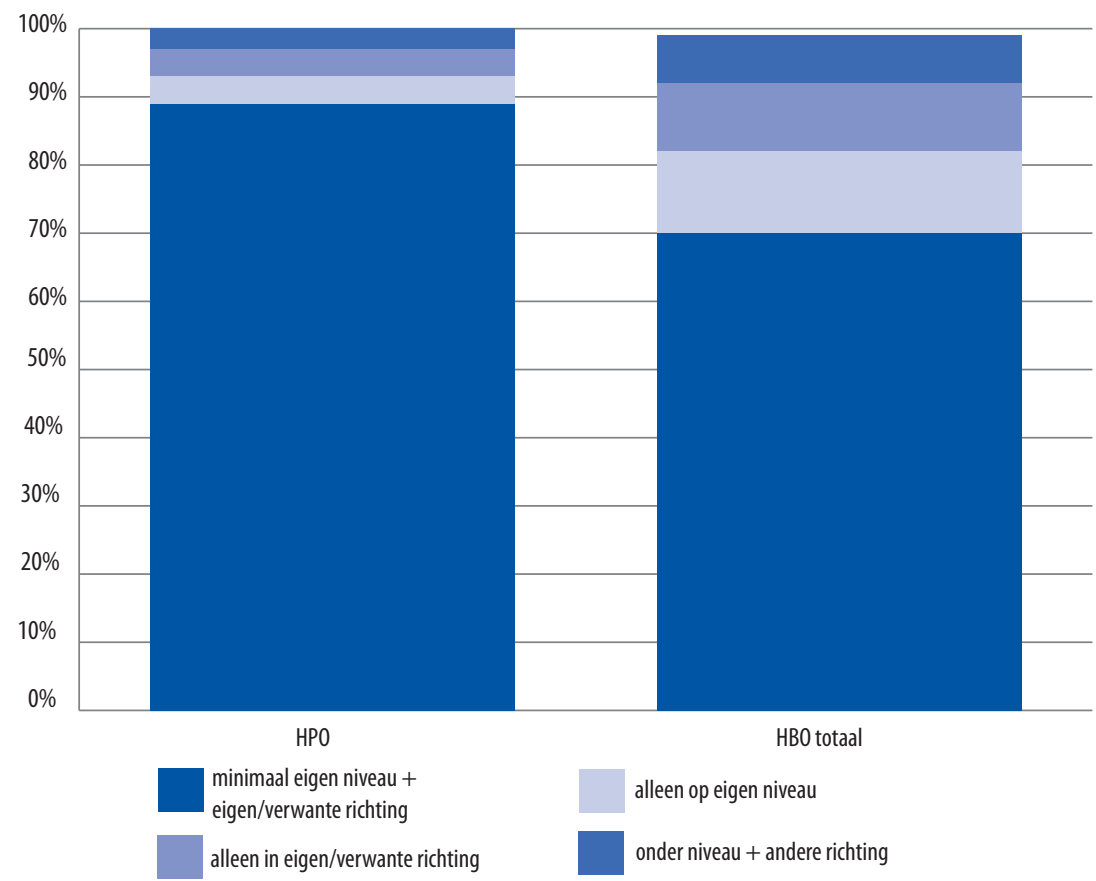

Bron: HBO-Monitor 2006-2010

Van de zeven onderscheiden opleidingssectoren komen afgestudeerden van het HPO relatief het vaakst in hun kerndomein terecht. 9 op de Io afgestudeerden van het HPO geven aan een baan te hebben op minimaal het eigen niveau én binnen de eigen of een verwante richting (figuur 2.5). Gemiddeld genomen hebben 7 op de Io recent afgestudeerden van het $\mathrm{HBO}$ een baan in het kerndomein. Dit kan waarschijnlijk verklaard worden door het specifieke karakter van veel HPO-opleidingen. Dit in tegenstelling tot opleidingen in bijvoorbeeld de sector economie, die veel generieker voor de betreffende sector opleidt. Ook werken afgestudeerden van het HPO I, 5 jaar later minder vaak dan gemiddeld zowel onder hun niveau alsook in een andere richting.

Veel van de overige baankenmerken van afgestudeerden worden in sterke mate bepaald door de vraag of ze binnen hun kerndomein werken of daarbuiten. Om dit te illustreren laat tabel 2.I een aantal baankenmerken zien voor afgestudeerden wiens huidige werk zowel naar niveau als naar richting aansluit bij de gevolgde opleiding, evenals voor afgestudeerden die óf naar richting, óf naar niveau, óf naar allebei niet aansluit bij de gevolgde HBO-opleiding. 
Tabel 2.1

Baankenmerken naar werken in/buiten kerndomein

\begin{tabular}{|c|c|c|c|c|c|c|}
\hline & $\begin{array}{l}\text { zelfstandige/ } \\
\text { freelancer }\end{array}$ & $\begin{array}{r}\text { tijdelijke } \\
\text { aanstelling }\end{array}$ & $\begin{array}{r}\text { part-time } \\
\text { werk }\end{array}$ & $\begin{array}{r}\text { aansluiting } \\
\text { opleiding- } \\
\text { werk }\end{array}$ & $\begin{array}{r}\text { reële } \\
\text { uurloon }\end{array}$ & $\begin{array}{l}\text { tevreden } \\
\text { met baan }\end{array}$ \\
\hline & $\%$ & $\%$ & $\%$ & $\%$ & gem. $€$ & $\%$ \\
\hline \multicolumn{7}{|l|}{ HPO } \\
\hline $\begin{array}{l}\text { minimaal eigen niveau + eigen/ } \\
\text { verwante richting }\end{array}$ & 0,5 & 47,3 & 39,9 & 88,8 & 13,69 & 75,8 \\
\hline alleen op eigen niveau & 1,6 & 54,6 & 35,2 & 60,8 & 13,03 & 69,2 \\
\hline alleen in eigen/verwante richting & 0,3 & 45,2 & 56,9 & 71,6 & 12,32 & 50,8 \\
\hline onder niveau + andere richting & 4,6 & 57,3 & 55,2 & 30,1 & 11,29 & 43,7 \\
\hline Totaal & 0,7 & 47,8 & 40,9 & 85,5 & 13,55 & 73,7 \\
\hline \multicolumn{7}{|l|}{ HBO totaal } \\
\hline $\begin{array}{l}\text { minimaal eigen niveau + eigen/ } \\
\text { verwante richting }\end{array}$ & 5,2 & 41,7 & 28,6 & 84.4 & 14.08 & 74.4 \\
\hline alleen op eigen niveau & 6,3 & 44,3 & 17,5 & 58,8 & 13,72 & 61,9 \\
\hline alleen in eigen/verwante richting & 3,4 & 43,6 & 41,5 & 69,8 & 12,67 & 51,5 \\
\hline onder niveau + andere richting & 3,7 & 54,7 & 38,0 & 32,8 & 11,33 & 33,1 \\
\hline Totaal & 5,1 & 43,1 & 29,2 & 76,1 & 13,69 & 67,6 \\
\hline
\end{tabular}

Bron: HBO-Monitor

Het aandeel HPO-afgestudeerden dat als zelfstandige of freelancers werkt is zoals verwacht erg gering in vergelijking met het $\mathrm{HBO}$-gemiddelde. Interessant genoeg geldt dat HPO-afgestudeerden vooral als zelfstandige of freelancers werken als ze zowel onder hun opleidingsniveau en buiten hun eigen richting werken. Werken in de eigen of verwante richting betekent een beduidend kleinere kans op een tijdelijke aanstelling, terwijl werken op minimaal het eigen niveau een beduidend kleinere kans op een parttime aanstelling betekent. Weinig verassend is de bevinding dat afgestudeerden die helemaal binnen hun eigen kerndomein werken veel vaker tevreden zijn over de aansluiting tussen de HBO-opleiding en hun werk. Interessant is wel het feit dat afgestudeerden die onder hun niveau werken maar binnen de eigen richting veel tevredener zijn over de aansluiting dan afgestudeerden die op minimaal eigen niveau werken maar buiten hun eigen richting werken. In termen van beloning en baantevredenheid ligt dit echter precies andersom. In de bijlage zijn de resultaten met betrekking tot het percentage dat binnen het kerndomein werkzaam is weergegeven per HPO Bachelor-opleiding. 


\section{Figuur 2.6}

Trend werkzaam in kerndomein (\%), 1998-2010

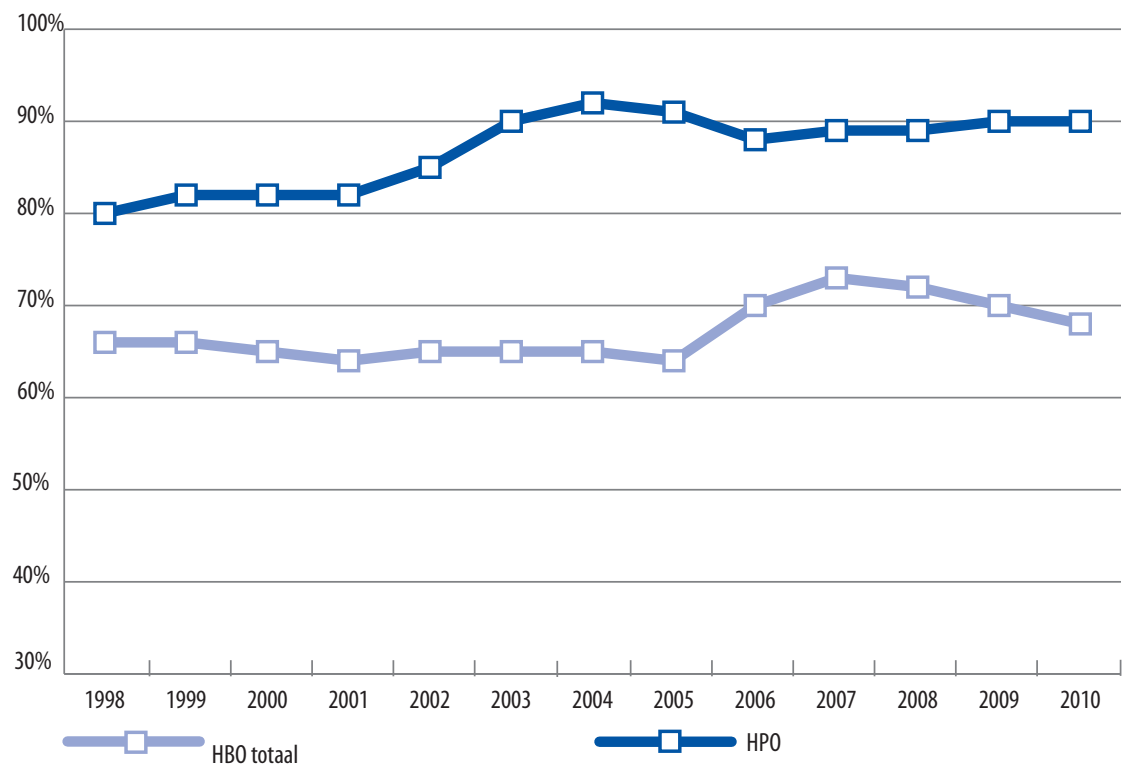

Bron: HBO-Monitor 1998-2010

Figuur 2.6 geeft aan hoe het percentage afgestudeerden dat binnen het kerndomein werkt verandert in de tijd. Afgestudeerden van het HPO werken in de periode 199820 Io veel vaker dan gemiddeld binnen hun kerndomein. Het is opvallend dat op deze indicator het totale $\mathrm{HBO}$ conjunctuur gevoelig is in de zin dat ten tijde van laagconjunctuur minder vaak binnen het kerndomein werkzaam is, maar dat dit niet op dezelfde wijze het geval is voor het HPO. Sterker nog, in de periode 2002-2005 (ten tijde van laagconjunctuur) steeg het aandeel HPO'ers dat binnen het kerndomein was zelfs met bijna IO\% ten opzichte van de periode ervoor. Ook in de recente crisis daalt het percentage niet voor de HPO'ers, waar het voor het HBO-gemiddelde wel daalt.

\section{Aansluiting opleiding-werk}

Recent afgestudeerden van het HPO oordelen over het algemeen een stuk gunstiger over de aansluiting tussen de gevolgde opleiding en werk in vergelijking met afgestudeerden van andere $\mathrm{HBO}$ richtingen (zie figuur 2.7). Van de afgestudeerden van het HPO beoordeelt gemiddeld $87 \%$ de aansluiting tussen de afgeronde opleiding en de baan tussen 1998 en 2010 als voldoende of goed, tegenover nog geen $80 \%$ van de afgestudeerden van het gehele $\mathrm{HBO}$. Voor het totale $\mathrm{HBO}$ is bovendien sprake van een dalende trend, terwijl dit voor het HPO niet het geval is. Sterker nog, in de periode 2002-2005 steeg het percentage HPO'ers dat de aansluiting goed/voldoende vond tot ruim 90\%. Waarschijnlijk niet geheel toevallig valt dit samen met de periode waarin relatief veel afgestudeerden van het HPO werk vonden binnen hun kerndomein. In 
dezelfde periode oordeelde de totale groep HBO'ers juist nog minder positief over de aansluiting.

\section{Figuur 2.7}

Trend goede/voldoende aansluiting tussen HBO-opleiding en werk (\%), 1998-2010

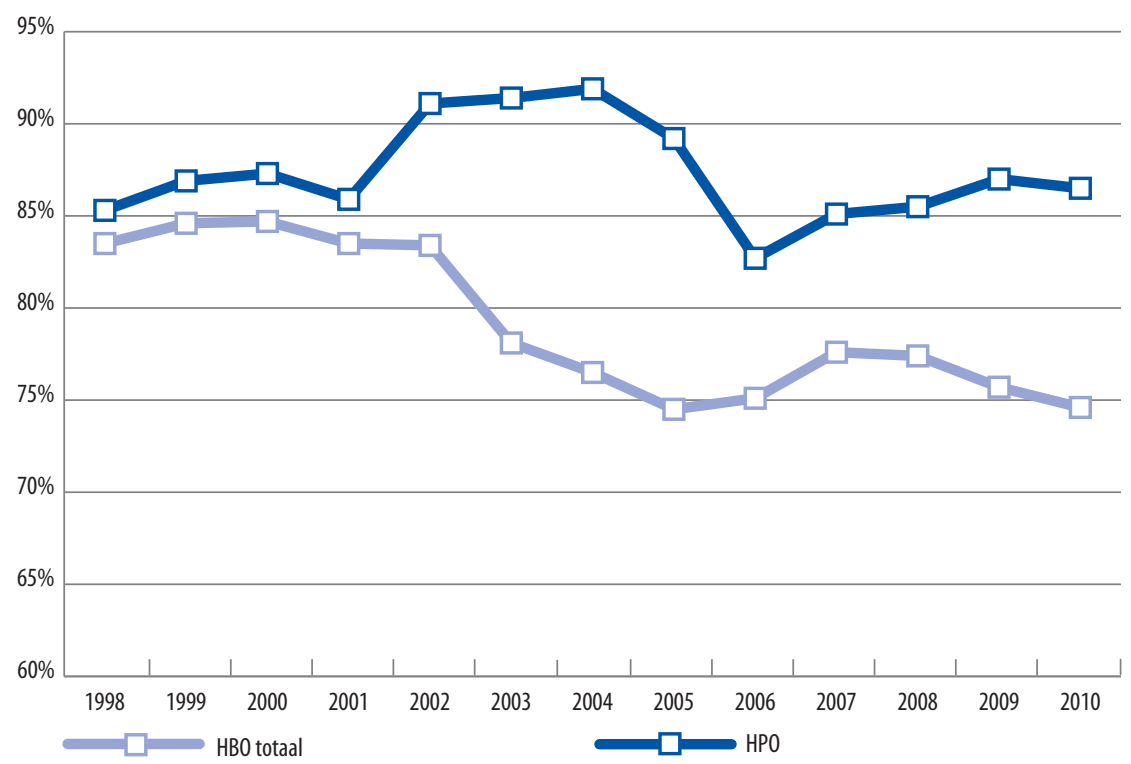

Bron: HBO-Monitor 1998-2010

Inkomen huidige baan

Figuur 2.8 laat zien dat het reële bruto uurloon van HBO-afgestudeerden erg conjunctuurgevoelig is. Tot en met 2005 lagen de reële bruto uurlonen van HPO-afgestudeerden doorgaans veel hoger dan het $\mathrm{HBO}$-gemiddelde. Dit was met name het geval wanneer er sprake was van hoogconjunctuur. Vervolgens leek het $\mathrm{HBO}$ als geheel een behoorlijke inhaalslag te maken en waren de lonen van afgestudeerden van het $\mathrm{HBO}$ als geheel een stuk hoger dan die van HPO-afgestudeerden. Sinds de economische crisis zien we dat het bruto uurloon van afgestudeerden van het $\mathrm{HPO}$ weer hoger ligt dan dat van het $\mathrm{HBO}$ als geheel. Dit wijst er op dat recent afgestudeerden van het $\mathrm{HBO}$ als geheel harder zijn geraakt door de crisis dan HPO-afgestudeerden. Sterker nog, het bruto uurloon van HPO-afgestudeerden stijgt zelfs sinds 2008. Tussen 1998 en $20 \mathrm{IO}$ is het reële bruto uurloon van recent afgestudeerden HBO'ers maar marginaal gestegen. Voor HPO-afgestudeerden nam dit toe met 44 eurocent. Zie de bijlage voor de gemiddelde bruto uurlonen per HPO Bachelor-opleiding. 


\section{Figuur 2.8}

Reële bruto uurloon huidige baan 2010 (euro), 1998-2010

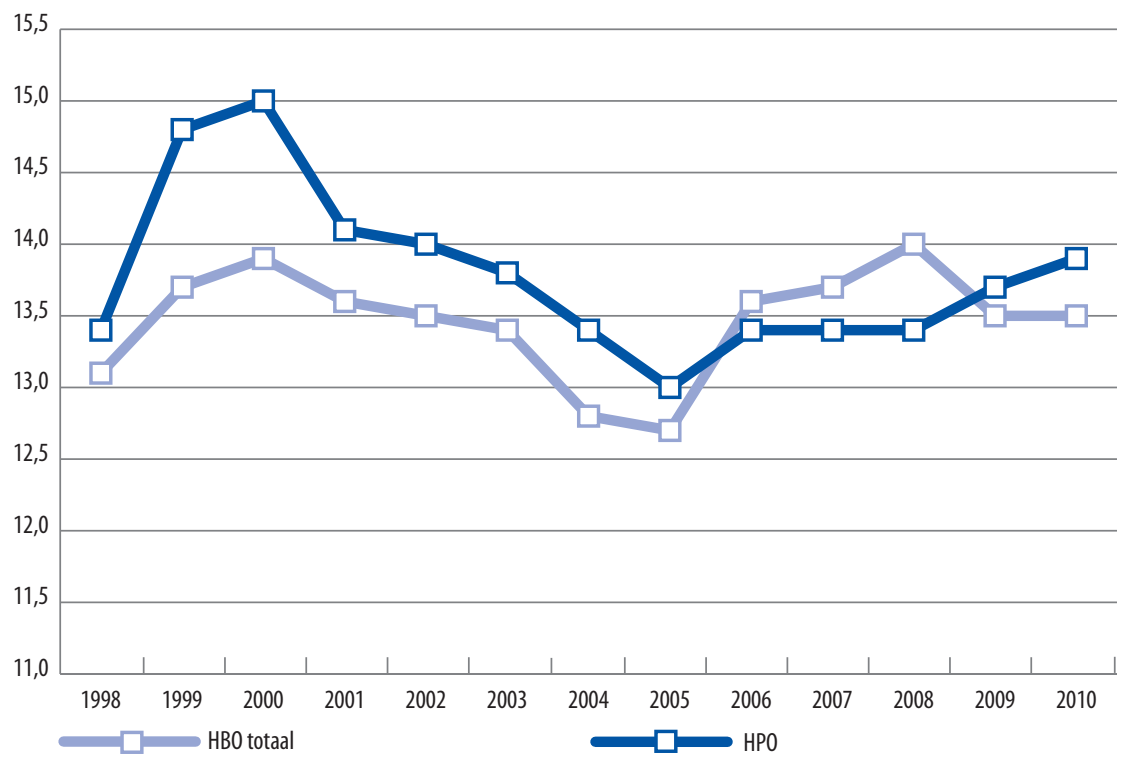

Bron: HBO-Monitor 1998-2010

Tevredenheid met huidige baan

Afgestudeerden van het HPO zijn in vergelijking met de totale groep werkende HBO'ers 1,5 jaar na het verlaten van de opleiding vaker tevreden met de huidige baan (figuur 2.9). Terwijl twee derde (67,3\%) van de totale groep recent afgestudeerde HBO'ers (zeer) tevreden is met de huidige baan, is dit onder de HPO-afgestudeerden gemiddeld $75,9 \%$. Zie de bijlage voor de tevredenheidspercentages per HPO Bacheloropleiding. 
Figuur 2.9

(Zeer) tevreden met huidige functie (\%), 2003-2010 3

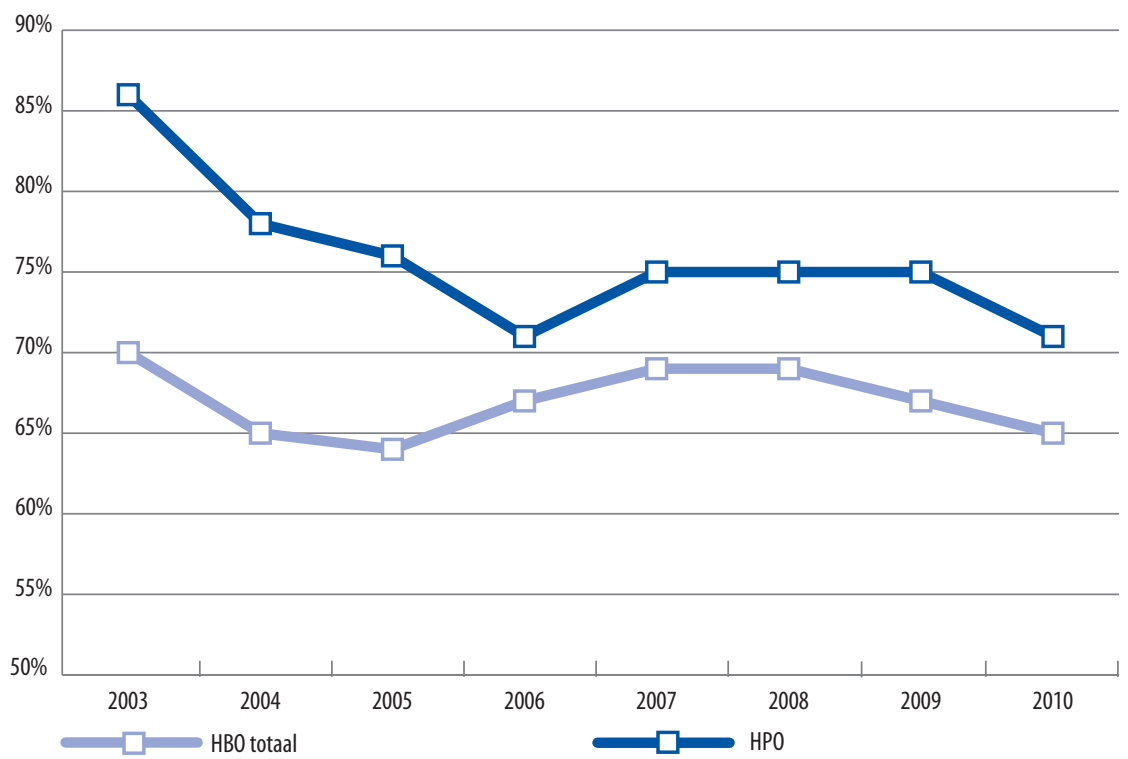

Bron: HBO-Monitor 2003-2010

\section{Spijt van de gekozen opleiding}

Op de vraag of afgestudeerden achteraf gezien opnieuw voor de gevolgde opleiding zouden kiezen of dat zij voor een andere opleiding zouden kiezen, antwoorden HPO-afgestudeerden positiever dan andere HBO'ers (figuur 2.IO). Binnen het HBO hebben HPO-afgestudeerden achteraf gezien het minste spijt van de gekozen opleiding. Gemiddeld genomen heeft I2,3\% van de HPO-afgestudeerden spijt van de gekozen opleiding, tegenover I op de 5 afgestudeerden voor het $\mathrm{HBO}$ als geheel. Tevens is er een dalende trend waarneembaar voor het HPO, wat betekent dat het percentage HPO-afgestudeerden dat achteraf gezien voor een andere dan de gevolgde opleiding zou kiezen afneemt over de tijd.

3. De variabele tevredenheid met de huidige baan is niet beschikbaar voor eerdere jaren. Enquêtevraag: Hoe tevreden bent u met uw huidige functie ( $\mathrm{I}$ 'zeer ontevreden' tot en met 5 'zeer tevreden'. Vermeld is het percentage van antwoordcategorie 4 en 5 . 


\section{Figuur 2.10}

Achteraf gezien spijt van de gekozen opleiding (\%), 1998-2010

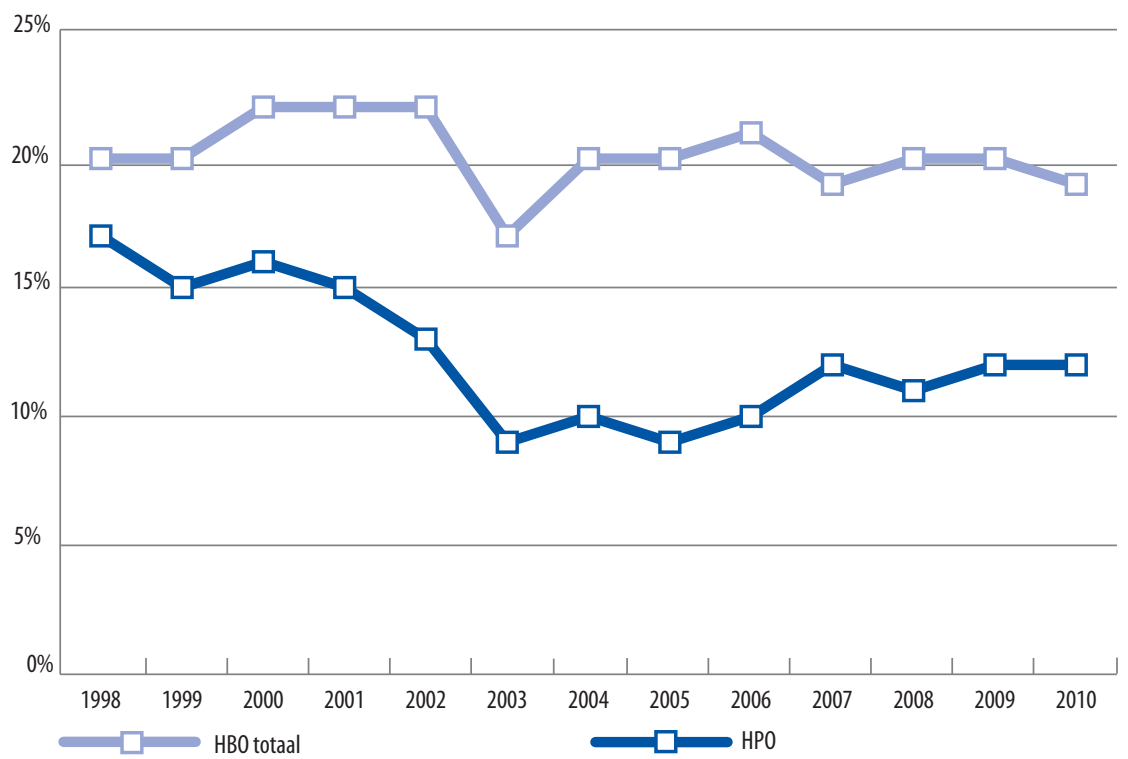

Bron: HBO-Monitor 1998-2010

\section{Cursus of bedrijfsopleiding gevolgd}

Tegenwoordig komt steeds meer nadruk te liggen op het belang van Leven Lang Leren, waarbij het belang van continue ontwikkeling van menselijk kapitaal tijdens de loopbaan centraal staat. In dit kader is het ook interessant om te bekijken of starters op de arbeidsmarkt die een HPO-opleiding gevolgd hebben zo kort na afstuderen al bijscholing hebben gekregen. Dit blijkt het geval te zijn voor $38 \%$ van de HPO'ers ten opzichte van $47 \%$ voor het $\mathrm{HBO}$ als geheel (figuur 2.II). Echter, het percentage neemt voor HPO-afgestudeerden enigszins toe in de tijd wat niet het geval lijkt te zijn voor het totale HBO. Tevens lijkt de deelname aan bijscholing bij HPO'ers minder gevoelig te zijn voor de conjunctuur dan het $\mathrm{HBO}$-gemiddelde. 
Figuur 2.11

Cursus of bedrijfsopleiding gevolgd (\%), 1998-2010

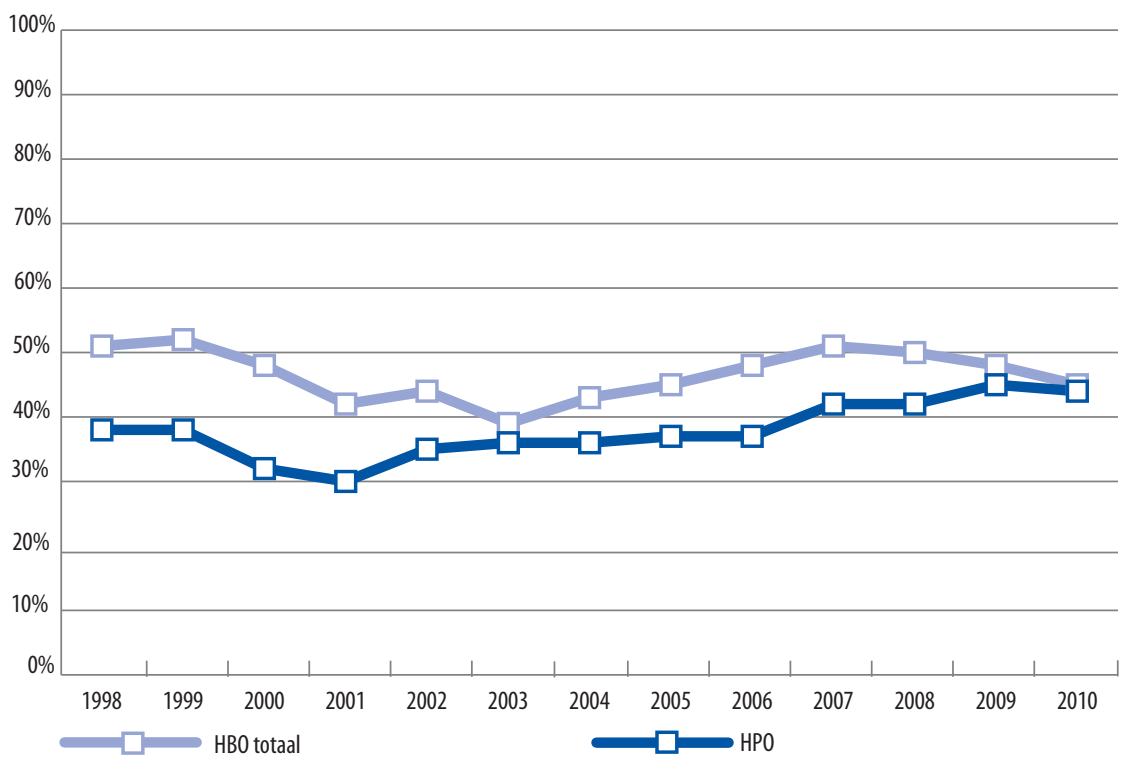

Bron: HBO-Monitor 1998-2010

\section{Contact met de hogeschool in verband met bijscholing}

Naast bovenstaande bijscholing in het algemeen kan ook gekeken worden naar de mate waarin de initiële hogeschool betrokken is geweest bij deze bijscholing. Figuren $2.12 \mathrm{a} t / \mathrm{m} 2.12 \mathrm{C}$ tonen in hoeverre afgestudeerden van de lerarenopleiding basisonderwijs (HPO-BO), ook wel de Pabo genoemd, en de lerarenopleidingen voorgezet onderwijs (HPO-VO), nog contact hebben met hun hogeschool in verband met bijscholing op basis van een 3-puntschaal: I 'ja', 2 'nee, maar zou dit best willen' en 3 'nee, geen behoefte aan'. Onder het HPO-VO vallen onder andere HBO-opleidingen als Leraar exact vak, Leraar lichamelijke opvoeding en Leraar maatschappij vak.

In de periode 2003-20I0 geven zowel de afgestudeerden van het HPO-BO als van het HPO-VO vaker dan HBO-gemiddeld aan dat ze ongeveer anderhalf jaar na afstuderen contact (willen) hebben met hun initiële hogeschool in verband met bijscholing. Bij het $\mathrm{HPO}-\mathrm{BO}$ en $\mathrm{HPO}-\mathrm{VO}$ schommelt dit percentage rond de $50 \%$, terwijl dat bij het $\mathrm{HBO}$-gemiddelde in de gehele periode zo'n $40 \%$ is. Bij het $\mathrm{HPO}-\mathrm{BO}$ zien we bovendien dat het percentage dat geen contact heeft met de hogeschool in verband met bijscholing maar dat wel zou willen de laatste jaren is gedaald, ten gunste van het 
percentage dat in dat verband wel contact heeft met de initiële hogeschool. Het lijkt erop dat de HPO-BO'ers die bijscholing willen, de weg naar hun initiële hogeschool steeds beter weten te vinden. Eenzelfde patroon is niet zichtbaar bij het HPO-VO of het $\mathrm{HBO}$-gemiddelde.

\section{Figuur 2.12}

Contact met de hogeschool in verband met het volgen van bijscholing, 2003-2010
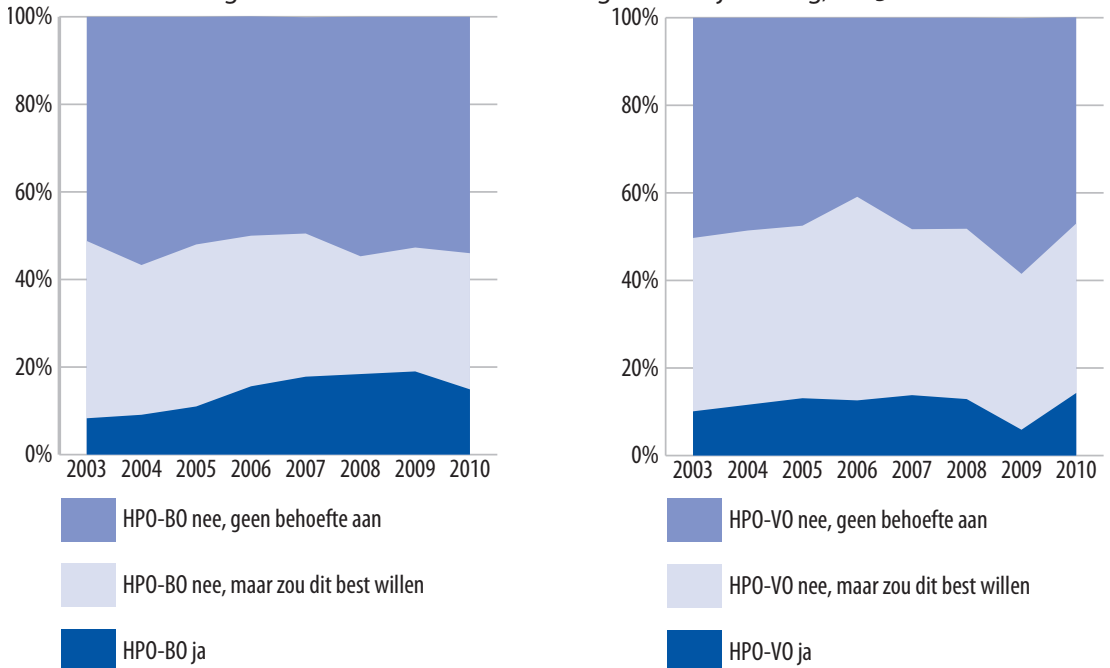

HPO-BO ja

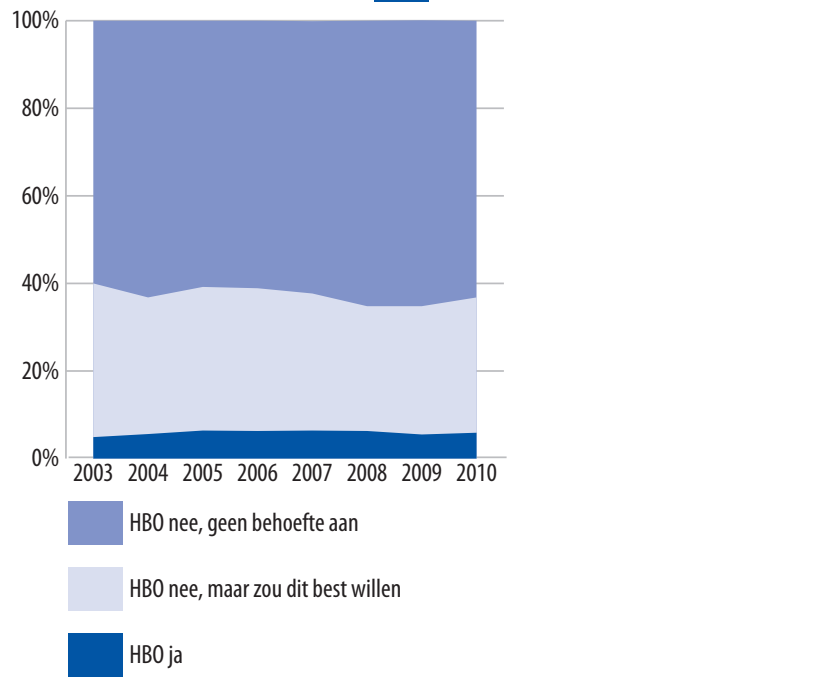

Bron: HBO-Monitor 2003-2010 
De onderwijsinspectie (OCW, 20II) heeft zorgen over de kritiek van HBO-afgestudeerden op de voorbereiding op de arbeidsmarkt. Een kwart van de afgestudeerden in het $\mathrm{HBO}$ is ontevreden over breedte en diepgang. In dit kader is het ook interessant om te bekijken wel oordeel starters op de arbeidsmarkt die een HPO-opleiding gevolgd hebben geven aan de breedte en diepgang van hun opleiding. Zo klagen Pabo-studenten al jaren dat de opleiding wel breed is maar niet diep. Studenten ervaren de studielast vooral in de vele taken en minder in de moeilijkheidsgraad. Vandaar dat ook hier een onderscheid wordt gemaakt tussen de lerarenopleiding basisonderwijs (HPO-BO) en de lerarenopleidingen voortgezet onderwijs (HPO-VO). Ter vergelijking zijn de gegevens voor het $\mathrm{HBO}$ als geheel ook opgenomen.

Figuren 2.I3a t/m 2.I3c tonen het oordeel over de opleiding met betrekking tot breedte op basis van een 7-puntschaal die loopt van respectievelijk I 'veel te smal' tot en met 7 'veel te breed'. Wanneer respondenten op deze schaal een 3,4 of 5 scoren, dan wordt dit geïnterpreteerd als dat zij tevreden zijn met de breedte van de opleiding (niet te smal en niet te breed). Het zojuist beschreven fenomeen van Pabostudenten (HPOBO) die ontevreden zijn met de breedte (en diepgang) van de opleiding, omdat de opleiding te breed zou zijn, is niet terug te zien in de figuren. Zowel de afgestudeerden van het HPO-BO als die van het HPO-VO waren iets vaker dan $\mathrm{HBO}$-gemiddeld tevreden over de breedte van de gevolgde opleiding (niet te breed en niet te smal). In de periode 2006-20IO vonden afgestudeerden van het HPO-BO zelfs minder vaak dan $\mathrm{HBO}$-gemiddeld dat de opleiding (veel) te breed was. Ook vergeleken met het HPO-VO vonden de HPO-BO'ers hun opleiding minder vaak (veel) te breed. Daarentegen is het percentage HPO-BO afgestudeerden dat de opleiding (veel) te smal vond (zo'n IO\%), de gehele periode hoger dan bij het HPO-VO (zo'n 8\%) en het HBO-gemiddelde (zo'n 5\%). 
Figuur 2.13

Oordeel over opleiding: breedte, 2006-2010 (\%)
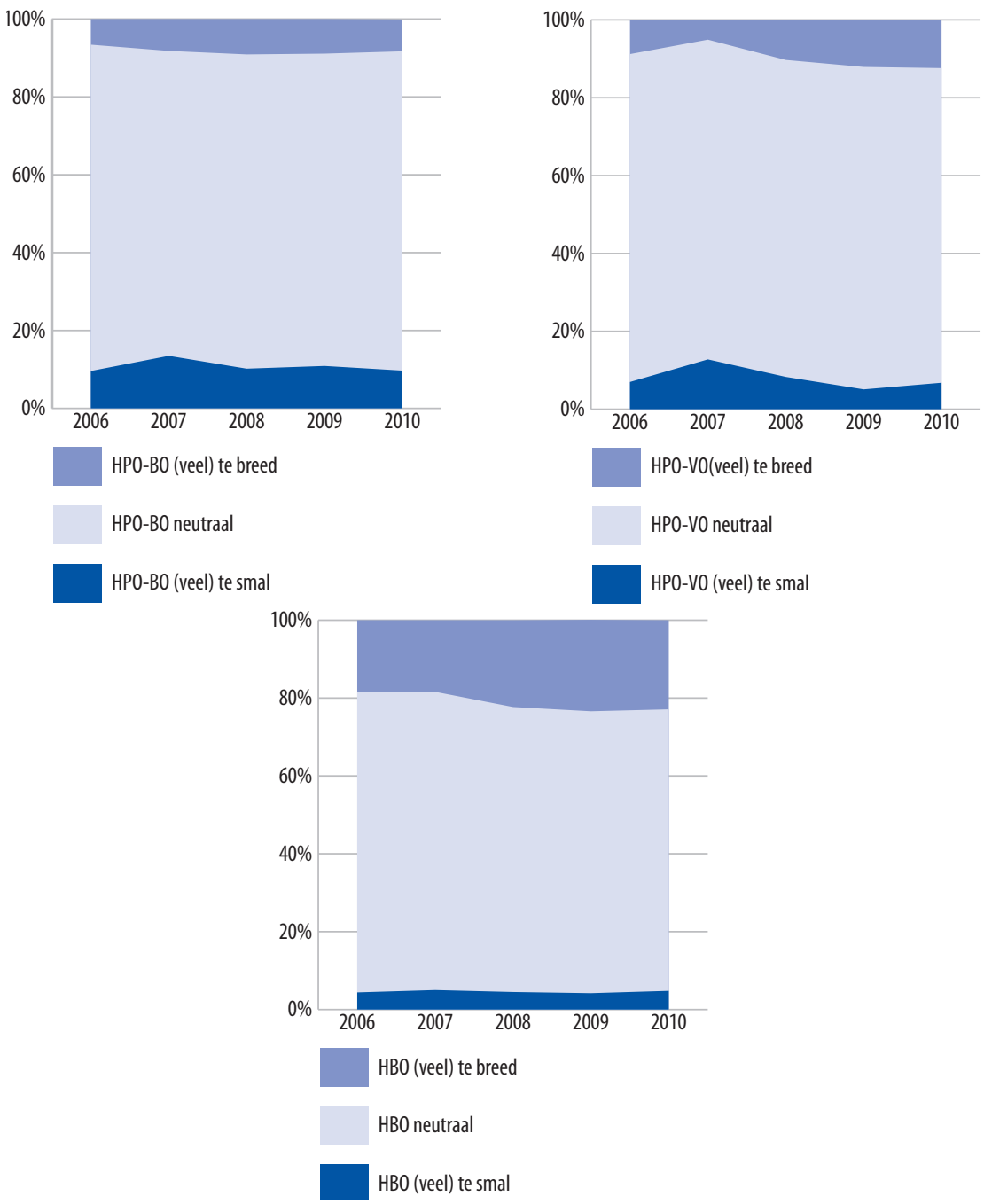

Bron: HBO-Monitor 2006-2010 


\section{Figuur 2.14}

Oordeel over opleiding: diepgang, 2006-2010
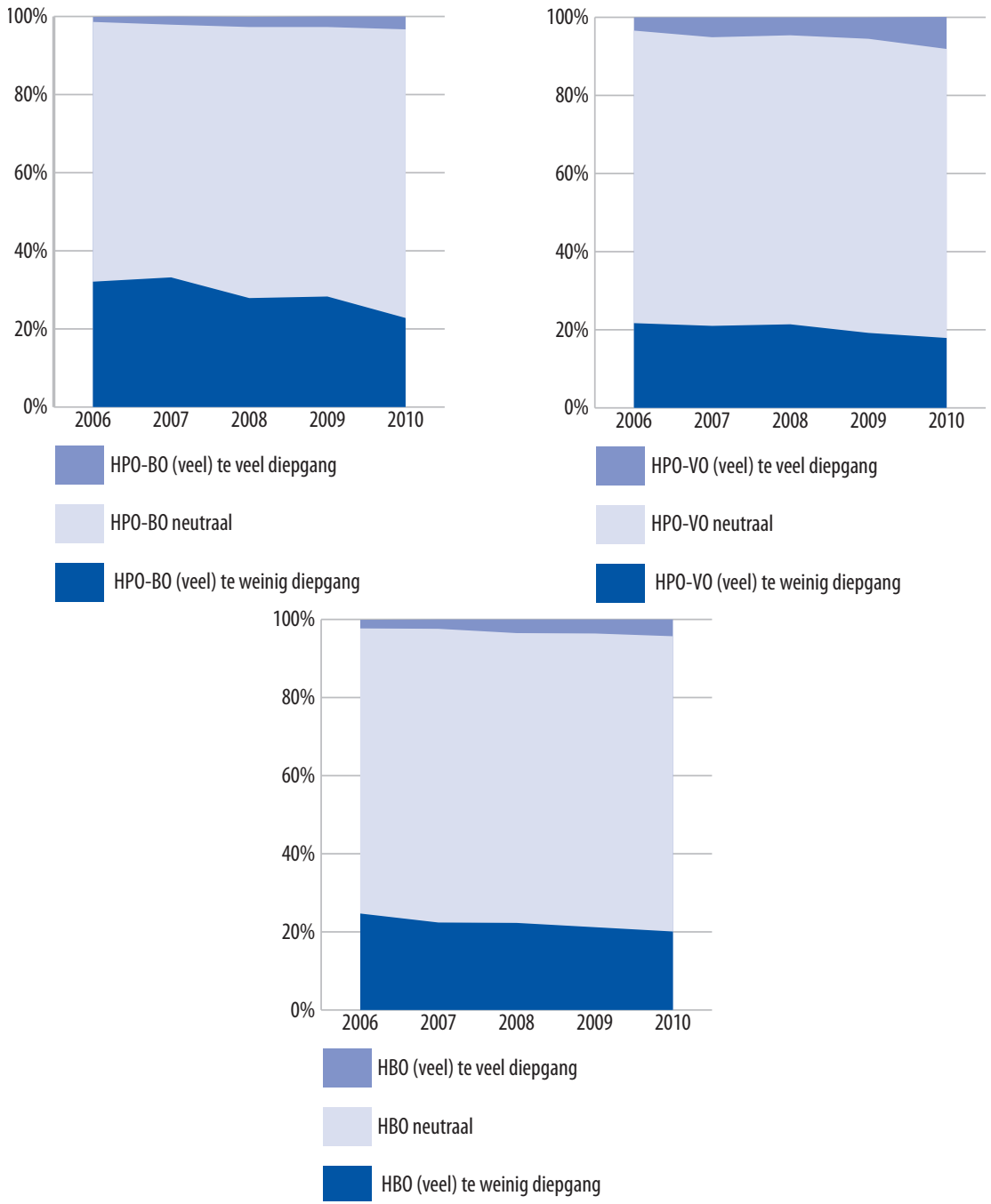

Bron: HBO-Monitor 2006-2010

Figuren 2.I4a t/m 2.I4c tonen het oordeel over de diepgang van de opleiding op basis van een 7-puntschaal die loopt van respectievelijk I 'veel te weinig diepgang' tot en met 7 'veel te veel diepgang'. Wanneer respondenten op deze schaal een 3,4 of 5 scoren, dan wordt dit geïnterpreteerd als dat zij tevreden zijn met de diepgang van de opleiding (niet te veel en niet te weinig). Hoewel een meerderheid van de HPO-BO afgestudeerden tevreden is met de diepgang van de opleiding, zijn zij minder vaak dan HBO-gemiddeld tevreden over de diepgang van de opleiding. Dit komt volledig 
door de relatief grote groep HPO-BO'ers die de opleiding (veel) te weinig diepgang vond hebben; het aandeel dat de opleiding (veel) te veel diepgang vond hebben is immers vrijwel gelijk. Dit komt overeen met het eerder beschreven fenomeen dat Pabostudenten vaker ontevreden zijn over de (breedte en) diepgang van de opleiding, omdat er te weinig diepgang zou zijn. Toch zien we dat het percentage HPO-BO'ers dat de opleiding (veel) te weinig diepgang vond hebben, de laatste jaren aan het dalen is ten gunste van het percentage HPO-BO'ers dat tevreden is over de diepgang van de gevolgde opleiding. Vergeleken met het HPO-BO en HBO-gemiddelde zijn de afgestudeerden van het HPO-VO juist relatief minder vaak van mening dat de opleiding (veel) te weinig diepgang had, en vinden zij relatief vaak dat de gevolgde HPO-VO opleiding (veel) te veel diepgang had. 


\section{Arbeidsmarktperspectieven}

In hoofdstuk 3 staat de arbeidsmarktdynamiek van de onderwijssector centraal. Tweejaarlijks biedt ROA een overzicht van de huidige en toekomstige arbeidsmarktontwikkelingen. Een belangrijk onderdeel hierin zijn de arbeidsmarktperspectieven voor schoolverlaters. Het toekomstig arbeidsmarktperspectief geeft voor de verschillende opleidingstypen de verhouding weer tussen vraag en aanbod van schoolverlaters en afgestudeerden in de prognoseperiode. In de meest recente versie gaat het om de periode 20II-20I6. De vraag- en aanbodprognoses zijn gebaseerd op de actuele arbeidsmarktpositie van een opleiding. Als het arbeidsmarktperspectief van een opleiding slecht is, betekent dit dat er de komende jaren veel meer aanbod van nieuwkomers zal zijn dan dat er baanopeningen zullen ontstaan. Hierdoor zal de arbeidsmarktpositie van deze afgestudeerden verslechteren. Deze verslechtering kan tot uiting komen in een hogere werkloosheid, maar door aanpassingsprocessen op de arbeidsmarkt kan de verslechtering van de arbeidsmarktsituatie ook leiden tot het moeten aanvaarden van banen op een lager niveau, tegen een lagere beloning of bijvoorbeeld een stijging van het aantal tijdelijke contracten. Omgekeerd zal een goed perspectief leiden tot een grotere kans op werk, maar ook tot een verbeterde positie op andere punten.

Het toekomst arbeidsmarktperspectief per opleidingstype wordt bepaald door middel van de Indicator Toekomstig Arbeidsmarktperspectief (ITA) ${ }^{4}$, die is gedefinieerd als de verhouding tussen enerzijds de verwachte arbeidsmarktinstroom van afgestudeerden en het aantal kortdurig werklozen en anderzijds de verwachte baanopeningen en de passieve substitutievraag. ${ }^{5}$ Naarmate de waarde van de indicator hoger is, wordt het perspectief slechter. De bijbehorende kwalitatieve typering van de arbeidsmarktperspectieven luidt respectievelijk zeer goed, goed, redelijk, matig of slecht. Daarnaast wordt ook de Indicator Toekomstige Knelpunten Personeelsvoorziening (ITKP) weergegeven, die aangeeft in hoeverre er personeelstekorten worden verwacht bij

4. Zie voor meer informatie over de arbeidsmarktperspectieven van schoolverlaters: ROA (2OII), De arbeidsmarkt naar opleiding en beroep tot 20I6, ROA-R-20II/8, Maastricht University.

5. Als gevolg van discrepanties tussen vraag en aanbod op de arbeidsmarkt treden er verschuivingen op in de werkgelegenheidsstructuur. Schoolverlaters in een aanbodoverschotsituatie kunnen anders opgeleiden gaan verdringen, terwijl werkgevers die te kampen hebben met een tekortschietend arbeidsaanbod, personen met een andere opleidingsachtergrond kunnen gaan werven. De vraag die hierdoor verloren gaat of ontstaat wordt aangeduid als het passieve substitutie-effect. Als het passieve substitutie-effect positief is, gaat het om extra baanopeningen als gevolg van tekorten bij andere opleidingen. Een negatief substitutie-effect duidt daarentegen op een verlies aan baanopeningen, omdat men verdrongen wordt door andere opleidingen. 
werkgevers in de verschillende sectoren. Door deze definiëring is het de verwachting dat hoe groter het verwachte personeelstekort in een sector is, hoe beter de verwachte arbeidsmarktperspectieven voor recent afgestudeerden zijn.

Het ROA (2OII) verwacht goede arbeidsmarktvooruitzichten voor afgestudeerden van $\mathrm{HPO}$-opleidingen, en de komende jaren worden er voor het HPO dan ook grote knelpunten in de personeelsvoorziening verwacht. In vergelijking met de andere $\mathrm{HBO}$-opleidingen, heeft het HPO de beste arbeidsmarktperspectieven, dat wil zeggen de laagste ITA score. Desondanks zijn de arbeidsmarktperspectieven voor HBO paramedisch en $\mathrm{HBO}$ techniek ook goed te noemen. De perspectieven voor $\mathrm{HBO}$ sociaalcultureel en $\mathrm{HBO}$ economie zijn echter matig.

Tabel 3.I geeft voor de opleidingscategorie HBO pedagogisch, evenals onderliggende opleidingstypen, weer welke arbeidsmarktperspectieven afgestudeerden de komende jaren tegemoet kunnen zien en waar knelpunten in de personeelsvoorziening worden verwacht. In het algemeen zullen de personeelstekorten in het onderwijs de komende jaren toenemen.

Binnen het HPO zijn de perspectieven voor $\mathrm{HBO}$ lerarenopleiding medisch en verzorging en $\mathrm{HBO}$ lerarenopleiding natuur en techniek zeer goed, wat samenhangt met de verwachting dat werkgevers van deze afgestudeerden zeer grote personeelstekorten (knelpunten) kunnen verwachten. Voor de HBO lerarenopleiding lichamelijke opvoeding is het arbeidsmarktperspectief matig, hier zullen vrijwel geen knelpunten in de personeelsvoorziening zijn.

Tabel 3.1

Toekomstige arbeidsmarktperspectieven naar opleiding (ITA) voor schoolverlaters, en toekomstige knelpunten in de personeelsvoorziening naar opleiding (ITKP), 2011-2016

\begin{tabular}{|l|l|l|l|l|}
\hline Opleidingscategorie & ITA & $\begin{array}{l}\text { Typering Arbeidsmarkt- } \\
\text { perspectieven }\end{array}$ & ITKP & $\begin{array}{l}\text { Typering Knelpunten in de } \\
\text { personeels-voorziening }\end{array}$ \\
\hline HBO lerarenopleiding basisonderwijs & 0,89 & goed & 0,90 & groot \\
\hline HBO lerarenopleiding talen & 0,86 & goed & 0,90 & groot \\
\hline HBO lerarenopleiding natuur en techniek & 0,81 & zeer goed & 0,83 & zeer groot \\
\hline HBO lerarenopleiding economie en maatschappij & 0,92 & goed & 0,94 & groot \\
\hline HBO lerarenopleiding lichamelijke opvoeding & 1,08 & matig & 1,11 & vrijwel geen \\
\hline HBO lerarenopleiding medisch en verzorging & 0,78 & zeer goed & 0,78 & zeer groot \\
\hline HBO lerarenopleiding expressie & 0,90 & goed & 0,92 & groot \\
\hline HBO onderwijs (HPO) totaal & 0,89 & goed & 0,90 & groot \\
\hline B & & & & \\
\hline
\end{tabular}

Bron: ROA (AIS)

ITA: Indicator Toekomstige Arbeidsmarktsituatie in 2016

ITKP: Indicator Toekomstige Knelpunten Personeelsvoorziening in 2016 


\section{Vereiste competenties voor afgestudeerden van het HPO}

In hoofdstuk 2 werd een korte schets gegeven van de arbeidsmarkt voor HPO'ers in het verleden en het heden, en in hoofdstuk 3 werden prognoses gepresenteerd van de verwachte ontwikkeling van de werkgelegenheid in de toekomst. Deze vooral kwantitatieve ontwikkelingen zijn interessant en belangrijk, maar zeggen weinig of niets over hoe het werk in de toekomst in kwalitatieve zin eruit zal zien. In dit hoofdstuk wordt een korte schets gegeven van enkele belangrijke ontwikkelingen in de sector en hoe het onderwijsveld op de te verwachten trends kan inspelen bij het opleiden van toekomstige arbeidskrachten voor de onderwijssector. De focus ligt hierbij op de competenties waar het Hoger Onderwijs zich op moet gaan richten. In paragraaf 4.I worden allereerst enkele algemene en sectorspecifieke trends aangestipt. In paragraaf 4.2 komt het vereiste competentieniveau aan bod van recent afgestudeerden die werkzaam zijn in hun kerndomein. Bovendien wordt hier besproken of bepaalde competenties door de jaren heen belangrijker zijn geworden. In paragraaf 4.3 komen vervolgens de ervaren competentietekorten aan bod.

\subsection{Trends en ontwikkelingen}

Voorbeelden van algemene sector overstijgende trends zijn onder meer demografische ontwikkelingen zoals vergrijzing en ontgroening, voortschrijdende technologische ontwikkelingen, de toenemende invloed van internet en ICT, heterogeniteit van de samenleving, individualisering en mondialisering, klimaatproblematiek en de verschuiving van het economisch zwaartepunt en de daarmee gepaard gaande internationale machtsverhoudingen.

Al deze trends kunnen op hun beurt vragen om specifieke competenties van de arbeidskrachten die werkzaam zijn in een sector, en dus indirect van invloed zijn op de inrichting van het Hoger Onderwijs. Deze ontwikkelingen leiden er immers toe dat bepaalde competenties belangrijker worden, terwijl andere competenties in de toekomst mogelijkerwijs juist minder van afgestudeerden gevraagd zullen worden.

Op basis van de literatuur kunnen er vier trends worden gedefinieerd die specifiek spelen in de onderwijssector: ontgroening, vergrijzing, toename innovatie in de leeromgeving en verbetering kennisbasis leraren. Hieronder worden deze trends toegelicht waarbij wordt aangegeven wat het belang van deze trends is voor de competenties die nu en in de toekomst van afgestudeerden van het HPO (zullen) worden verwacht. 


\section{Ontgroening: krimp van het leerlingenaantal}

De ontgroening van de Nederlandse samenleving is een algemene trend die specifieke gevolgen heeft voor de onderwijssector. Volgens de meest recente bevolkingsprognose van het Centraal Bureau voor de Statistiek (CBS, 20I0) krimpt in Nederland de leeftijdscategorie O-I9 jaar tussen 2009 en 2030 met 5 procent. Hierdoor zal naar verwachting het leerlingenaantal in het primair- en voortgezet onderwijs de komende jaren in heel Nederland dalen. In de ene regio zal de krimp sterker zijn dan in de andere (SBO, 20IO). Door het teruglopende leerlingenaantal zal er flexibel moeten worden omgegaan met o.a. huisvesting (denk aan fusies tussen scholen) en het personeelsbestand. Daarnaast blijkt uit een enquête van het SBO (20IO) dat een daling van het leerlingenaantal ook effect heeft op het onderwijsaanbod (verschraling van het vakkenaanbod) en de interne organisatie van scholen (bijvoorbeeld combinatiegroepen en afschaffing remedial teaching). De Taskforce Onderwijs en Demografische Omslag (2009) waarschuwt daarom voor risico's voor de kwaliteit, diversiteit en spreiding van het onderwijs.

\section{Vergrijzing in de sector}

In Nederland is $33 \%$ van de docenten in het primair onderwijs en $44 \%$ van de docenten in het voortgezet onderwijs 50 jaar of ouder. Voor de EU als geheel is dit $28 \%$ en $36 \%$ (Allen en Van der Velden, 20II). Het teruglopende leerlingenaantal en de bezuinigingen in het onderwijs leiden tot een (regionaal) overschot aan leraren (Nationaal Netwerk Bevolkingsdaling, 2009). Indien het natuurlijk verloop beperkt is en scholen/besturen bij (dreigend) ontslag vast blijven houden aan het 'last in-first out' principe, zal dit leiden tot een (verdere) vergrijzing van het personeelsbestand (SBO, 2OIO). Zoals alle oudere mensen, zijn oudere leraren onderhevig aan cognitief verval. Als gevolg daarvan zal hoogstwaarschijnlijk hun vermogen om nieuwe informatie te verwerken, zich aan te passen aan veranderingen in de omgeving, enzovoorts dalen (Allen en Van der Velden, 2OII). Aangezien ICT tools en innovatieve leeromgevingen steeds belangrijker worden in het primair- en voortgezet onderwijs (OECD, 20IO), is dit een belangrijk aandachtspunt voor de toekomst.

\section{Toename innovatie in de leeromgeving}

De afgelopen twee decennia zijn er veel aanhangers geweest van innovatieve methoden om '2Ist century skills' te ontwikkelen (OECD, 20IO). In Nederland wordt in de meeste (zo niet alle) programma's in het secundaire (VO en $\mathrm{MBO}$ ) en tertiaire ( $\mathrm{HBO}$ en WO) onderwijs een bepaalde vorm van student-gecentreerde methode gebruikt, waarbij de doelstellingen gedefinieerd zijn in competenties, waarbij de rol van de docent die van bemiddelaar/adviseur/gids is. Door ICT is het mogelijk om persoonlijke leerplannen op te zetten die geïntegreerd worden in interactieve leeromgevingen (eventueel met een e-docent). Deze individuele leeromgevingen worden onderling 
met elkaar verbonden zodat het mogelijk is om samenwerkingsprojecten uit te voeren, hetgeen de mogelijkheden voor 'informeel leren' vergroot (ECJRC, 20II). Door het gebruik van moderne technologie rukken bovendien gemeenschappen van onderwijswerkers op die samen curricula ontwikkelen en ze toegankelijk maken via 'open resources'. Leraren kunnen kiezen uit materiaal dat al ergens anders ontwikkeld is. Studenten kunnen colleges volgen van de beste docenten ter wereld (Allen en Van der Velden, 20II). Toch is het aandeel leraren dat zich volledig bewust is van de didactische mogelijkheden van ICT vrij laag (Kennisnet, 20IO).

\section{Verbetering kennisbasis leraren}

De Pabo's en lerarenopleidingen zijn in het recente verleden ernstig tekortgeschoten op rekenen en taalbeheersing. Voor de lerarenopleidingen zijn er daarom in 2009 kennisbases ontwikkeld, welke de basiskwaliteit van de lerarenopleidingen garanderen. De Pabo's hebben het afgelopen jaar de kennisbases voor de vakken rekenen-wiskunde en Nederlandse taal vastgelegd. Voor de tweedegraads lerarenopleidingen bestaat de kennisbasis per schoolvak voor 50\% uit vakkennis (bijvoorbeeld Frans of Wiskunde) en voor 50\% uit praktijkkennis (bijvoorbeeld pedagogiek, didactiek en praktijkstages) (HBO-raad, 20IO). Begin 2012 is besloten dat bij Pabo's bovendien meer aandacht zal worden besteed aan het toetsen van kennis en vaardigheden van Engels, geschiedenis, aardrijkskunde en natuur en techniek (ANP, 20I2a). Ook moeten studenten zich tijdens en na hun studie specialiseren.

Allen en Van der Velden (2OII) concluderen dat de veranderingen in de kennis economie meer dan alleen de ontwikkelingen van "2Ist century skills" vereisen, maar ook verdere verbeteringen van het niveau van basic skills zoals taal en rekenen vereisen.

\subsection{Vereist niveau competenties}

Gebruikmakend van gegevens uit de HBO-Monitor wordt in deze paragraaf ingegaan op het competentieniveau dat vereist is voor afgestudeerden van het HPO die in hun kerndomein (aansluiting opleiding-werk naar zowel opleidingsniveau als opleidingsrichting) werkzaam zijn. Tabel 4.I toont het vereiste competentieniveau op basis van een 5-puntschaal die loopt van I 'matig niveau vereist' tot en met 5 'uitmuntend niveau vereist'. Om een beeld te krijgen van de mate waarin de competentievereisten aan het veranderen zijn, wordt tevens de trend in deze vereisten berekend. Zo wordt een beeld gegeven van de gemiddelde jaarlijkse toe- of afname. De trend wordt alleen getoond wanneer deze statistisch significant is. ${ }^{6}$

6. De trends zijn berekend door middel van regressieanalyses, waarbij het effect van het aantal jaren verstreken vanaf $2004(2004=0$... 20IO=6) op het vereist niveau van de verschillende competenties is berekend. Om het effect van mogelijke verschuivingen in de compositie van de sector naar opleiding of hogeschool uit te zuiveren, worden dummy's opgenomen voor alle opleidingen en scholen die in de sector zijn vertegenwoordigd. 
Het vereiste competentieniveau onder afgestudeerden van het Hoger Pedagogisch Onderwijs is vrij hoog voor de meeste competenties en hetzelfde kan geconcludeerd worden voor het $\mathrm{HBO}$-gemiddelde. Het vereiste niveau is volgens afgestudeerden van het HPO het hoogst wat betreft het vermogen om aan anderen duidelijk te maken wat men bedoelt en zelfstandig de werkzaamheden uit te voeren. Ook het vermogen om problemen en kansen te signaleren, vakkennis in de praktijk toe te passen, nieuwe ideeën en oplossingen te bedenken en productief met anderen samen te werken zijn competenties die in belangrijke mate door de werkgever gevraagd worden in hun huidige functie. Ondanks de globalisering en internationaal georiënteerde economie blijk het vereiste niveau van de communicatie in een buitenlandse taal het laagst van alle 23 onderscheiden competenties. Andere competenties waarbij het vereiste niveau bij de start van de loopbaan relatief laag is zijn de kennis van andere vakgebieden en het vermogen om informatie- en communicatietechnologie te gebruiken en conform budget, planning of richtlijnen te werken.

In algemene zin wijkt het vereiste competentieniveau voor HPO'ers niet veel af van het $\mathrm{HBO}$-gemiddelde. Het grootste verschil is terug te zien bij het vermogen om te communiceren in een buitenlandse taal. Bij afgestudeerden van het HPO ligt het vereiste niveau aanzienlijk lager dan bij andere HBO'ers, wat zeer waarschijnlijk verklaard kan worden door het nationale karakter van deze sector. Andere verschillen zijn dat het vereiste niveau om conform budget, planning of richtlijnen te werken, informatie- en communicatietechnologie te gebruiken en informatie te vergaren minder hoog is voor HPO'ers dan voor het HBO-gemiddelde. Hier staat tegenover dat van HPO'ers, in vergelijking met het HBO-gemiddelde, een hoger niveau verwacht wordt wat betreft de kennis van het eigen vakgebied, het toe kunnen passen van vakkennis in de praktijk en het kunnen bedenken van nieuwe ideeën en oplossingen.

Daarnaast is het interessant om te bekijken welke competenties de laatste jaren belangrijker worden. Uit tabel 4.I blijkt eveneens dat voor bijna de helft van de competenties geldt dat het vereiste niveau tussen 2004 en 2010 significant gestegen is. In het bijzonder het vermogen om informatie- en communicatietechnologie in de praktijk toe te passen blijkt in toenemende mate van afgestudeerde HPO'ers gevraagd te worden. Andere competenties die de laatste jaren meer en meer op een hoog niveau van HPO'ers gevraagd worden, zijn bijvoorbeeld het in staat zijn capaciteiten van anderen aan te bespreken en het communiceren in buitenlandse talen. Het laatste zou ermee te maken kunnen hebben dat Engels onder de eerder beschreven kennisbasis van leraren valt. Hier staat overigens opvallend genoeg tegenover dat van HPO'ers de laatste jaren een lager niveau gevraagd wordt wat betreft het bedenken van nieuwe ideeën en oplossingen en het logisch kunnen redeneren. 
Tabel 4.1

Vereist competentieniveau, 2004-2010*

\begin{tabular}{|c|c|c|c|c|}
\hline & $\begin{array}{l}\text { HPO } \\
\text { gem. }\end{array}$ & trend & $\begin{array}{r}\text { HBO-totaal } \\
\text { gem. }\end{array}$ & trend \\
\hline \multicolumn{5}{|l|}{ Kennis van: } \\
\hline eigen vakgebied & 4,0 & 0,012 & 3,8 & 0,012 \\
\hline andere vakgebieden & 3,3 & n.s. & 3,3 & n.s. \\
\hline \multicolumn{5}{|l|}{ Vermogen om: } \\
\hline vakkennis in de praktijk toe te passen & 4,1 & 0,010 & 3,9 & 0,010 \\
\hline informatie- \& communicatietechnologie te gebruiken & 3,4 & 0,039 & 3,6 & 0,021 \\
\hline in buitenlandse talen te communiceren & 2,0 & 0,015 & 2,5 & n.s. \\
\hline informatie te vergaren & 3,7 & n.s. & 3,9 & n.s. \\
\hline problemen en kansen te signaleren & 4,2 & n.s. & 4,1 & 0,011 \\
\hline verbanden te leggen tussen verschillende zaken & 3,9 & n.s. & 4,0 & 0,011 \\
\hline hoofd- van bijzaken te onderscheiden & 3,8 & n.s. & 3,9 & n.s. \\
\hline logisch te redeneren & 3,9 & -0.011 & 4,0 & n.s. \\
\hline conform budget, planning of richtlijnen te werken & 3,3 & n.s. & 3,6 & 0,014 \\
\hline onder druk goed te functioneren & 4,0 & n.s. & 4,0 & n.s. \\
\hline knopen door te hakken & 3,7 & n.s. & 3,7 & 0,012 \\
\hline nieuwe ideeën en oplossingen te bedenken & 4,1 & $-0,014$ & 3,9 & n.s. \\
\hline nieuwe dingen te leren & 4,0 & n.s. & 4,0 & n.s. \\
\hline aan anderen duidelijk te maken wat u bedoelt & 4,3 & n.s. & 4,2 & n.s. \\
\hline productief met anderen samen te werken & 4,1 & n.s. & 4,0 & n.s. \\
\hline capaciteiten van anderen aan te spreken & 3,8 & 0,016 & 3,7 & 0,017 \\
\hline zelfstandig de werkzaamheden uit te voeren & 4,3 & n.s. & 4,3 & n.s. \\
\hline \multicolumn{5}{|l|}{ Bereidheid om: } \\
\hline de nek uit te steken & 3,9 & 0,013 & 3,8 & 0,011 \\
\hline eigen en andermans ideeën ter discussie te stellen & 3,9 & n.s. & 3,8 & n.s. \\
\hline voor eigen standpunt op te komen & 3,9 & n.s. & 3,8 & n.s. \\
\hline begrip te tonen voor andere standpunten & 4,0 & n.s. & 3,9 & 0,009 \\
\hline
\end{tabular}

* Gemiddeld antwoord op 5-puntschaal (1'matig'<-> 5'uitmuntend') Bron: HBO-Monitor 2004-2010

Trends alleen vermeld als die op minstens 5\%-niveau significant zijn. Data voor HBO-totaal hierbij herwogen.

Binnen het HPO lijkt het niveau van de vereiste competenties minder te veranderen dan in het gehele HBO. Terwijl tussen 2004 en 2010 binnen het HPO 8 van de 23 competenties een significante verandering hebben doorgemaakt qua vereist niveau, zijn dit binnen het totale $\mathrm{HBO}$ I5 van de 23 competenties. Bij het totale $\mathrm{HBO}$ neemt vooral het belang van ICT-vaardigheden de afgelopen jaren sterk toe. Ook het vereiste competentieniveau voor het aanspreken van andermans capaciteiten zit sterk in de lift. Met uitzondering van de competentie vermogen om in buitenlandse talen te communiceren, nemen alle competenties met een significante positieve trend bij het $\mathrm{HPO}$ eveneens significant positief toe voor het totale $\mathrm{HBO}$. De competenties met een 
significant negatieve trend bij het $\mathrm{HPO}$ zijn voor het totale $\mathrm{HBO}$ niet significant. Bij een vergelijking van de trends voor afzonderlijke competenties tussen het $\mathrm{HPO}$ en het totale $\mathrm{HBO}$ springt er één enkele specifieke competentie uit. Zo neemt het vereiste niveau van het vermogen om informatie- en communicatietechnologie te gebruiken bij het HPO relatief sterk toe ten opzichte van het totale HBO. Toch is het vereiste niveau van het vermogen om ICT te gebruiken nog steeds lager bij het HPO dan bij het $\mathrm{HBO}$-gemiddelde. Dit geeft aan dat het vereiste niveau van het gebruik van ICT voor het HPO eerst heel laag was, maar dat er nu een inhaalslag plaatsvindt. Het is waarschijnlijk dat dit te maken heeft met de beschreven toename van innovatie in de leeromgeving.

\subsection{Competentietekorten}

Het is de vraag hoe het onderwijs op het veranderde belang van competenties heeft gereageerd. Heeft het toenemende belang van enkele competenties bij het HPO geresulteerd in tekorten voor de betreffende competenties, of heeft het onderwijs deze ontwikkelingen weten bij te benen door het niveau van deze competenties bij afgestudeerden op te krikken? Zijn er los van de besproken trends in het vereiste niveau ook competenties waarbij sprake is van een meer structureel tekort? Tabel 4.2 toont de competentietekorten zoals deze ervaren worden door afgestudeerden die in hun kerndomein werkzaam zijn. De resultaten worden vergeleken tussen het $\mathrm{HPO}$ en het totale $\mathrm{HBO}$. Omdat in de $\mathrm{HBO}-$ Monitor zowel het vereiste competentieniveau als het eigen competentieniveau op eenzelfde 5-puntschaal (I'matig' <-> 5 'uitmuntend') is gemeten, geeft de verschilscore voor iedere competentie een indicatie van een eventueel tekort of overschot. Van een competentietekort is sprake wanneer het vereiste niveau hoger is dan het eigen niveau. Het is belangrijk op te merken dat een tekort niet noodzakelijkerwijs negatief hoeft te zijn. Wanneer er namelijk sprake is van een klein tekort wordt dit vaak ervaren als een uitdaging om dit punt te verbeteren. Wanneer afgestudeerden het gevoel hebben dat zij al een bepaald niveau bereikt hebben, zouden zij wel eens gemakzuchtig kunnen worden en geen noodzaak zien om zich te blijven ontwikkelen op dat punt. Wel kan er een signaalfunctie van deze tekorten uitgaan. Net als bij het vereiste niveau wordt tevens de trend in tekorten, m.a.w. de gemiddelde jaarlijkse toe- of afname weergegeven. De trend wordt berekend op dezelfde wijze als bij het vereist competentieniveau (tabel 4.2) en wordt alleen weergegeven wanneer deze statistisch significant is.

Afgestudeerden van het HPO ervaren het grootste competentietekort als het gaat om het signaleren van problemen en kansen, en kennis van het eigen vakgebied. Bijna 4 van de Io afgestudeerde HPO'ers die werkzaam zijn in het kerndomein ervaart een tekort bij het vergelijken van het eigen niveau met het niveau dat voor de functie vereist is. Extra aandacht zou besteed moeten worden aan de bevinding dat het grootste ervaren competentietekort voor HPO'ers 'kennis van eigen vakgebied' is, aangezien uit de vorige paragraaf bleek dat juist voor deze competentie het vereiste 
niveau vrij hoog is en significant stijgt. Blijkbaar kan het onderwijs van het HPO het stijgende vereiste niveau van deze competentie niet (voldoende) bijbenen.

Ook schiet naar eigen zeggen het vermogen om vakkennis in de praktijk toe te passen, aan anderen duidelijk te maken wat men bedoelt, nieuwe ideeën en oplossingen te bedenken, onder druk goed te functioneren, en de bereidheid om voor het eigen standpunt op te komen vaak tekort. Ruim 3 van de Io afgestudeerde HPO'ers ervaren bij bovengenoemde competenties een tekort. Van de competenties het vermogen om vakkennis in praktijk toe te passen en nieuwe ideeën en oplossingen te bedenken werd in de vorige paragraaf vastgesteld dat het vereiste niveau vrij hoog is en significant stijg. Ook voor deze competenties lijkt het onderwijs het vereiste niveau niet te kunnen bijbenen.

Verder ervaart gemiddeld een kwart van de afgestudeerden van het HPO een competentietekort met betrekking tot de bereidheid om eigen en andermans ideeën ter discussie te stellen en het vermogen om knopen door te hakken, verbanden te leggen tussen verschillende zaken, hoofd- van bijzaken te onderscheiden en de kennis van andere vakgebieden. Over het niveau van competenties zijn HPO-afgestudeerden een stuk tevredener. Met betrekking tot het vermogen om logisch te redeneren en de bereidheid om begrip te tonen voor andere standpunten ervaart 'slechts' $15 \%$ een tekort. Het ervaren tekort is het laagst met betrekking tot het vermogen om informatie te vergaren (bijna I4\%) en in buitenlandse talen te communiceren (ruim $7 \%$ ).

In algemene zin kan geconcludeerd worden dat het HPO qua ervaren competentietekorten niet zo gek veel afwijkt van het $\mathrm{HBO}$-gemiddelde. De grootste verschillen bestaan tussen het HPO en het totale $\mathrm{HBO}$ als het gaat om de tekorten over het vermogen om conform budget, planning of richtlijnen te werken en in buitenlandse talen te communiceren. In beide gevallen ervaart een kleiner deel van de HPO'ers een tekort dan andere studiegenoten van het HBO. Andere competenties waar HPO'ers relatief minder tekorten ervaren zijn het vermogen om hoofd- van bijzaken te onderscheiden, informatie te vergaren, logisch te redeneren en knopen door te hakken. Hier tegenover staan verschillende competenties waar HPO'ers in vergelijking met het $\mathrm{HBO}$-gemiddelde juist relatief vaak tekorten ervaren. Dit verschil is het grootst bij het signaleren van problemen en kansen, het aanspreken van de capaciteiten van anderen en het toepassen van de vakkennis in de praktijk. Andere competenties waar afgestudeerden van het HPO een groter tekort ervaren dan andere studiegenoten van het $\mathrm{HBO}$ zijn bijvoorbeeld opkomen voor het eigen standpunt, het ter discussie stellen van eigen en andermans ideeën, productief met anderen samen werken, kennis van het eigen vakgebied, goed functioneren onder druk en het bedenken van nieuwe ideeën en oplossingen. 
Tabel 4.2

Ervaren tekort met betrekking tot competenties* (\%)

\begin{tabular}{|c|c|c|c|c|}
\hline & $\begin{array}{l}\text { HPO } \\
\text { gem. }\end{array}$ & trend & $\begin{array}{r}\text { HBO-totaal } \\
\text { gem. }\end{array}$ & trend \\
\hline \multicolumn{5}{|l|}{ Kennis van: } \\
\hline eigen vakgebied & 39,4 & 0,733 & 36,5 & n.s. \\
\hline andere vakgebieden & 24,8 & n.s. & 25,8 & n.s. \\
\hline \multicolumn{5}{|l|}{ Vermogen om: } \\
\hline vakkennis in de praktijk toe te passen & 33,8 & n.s. & 28,6 & n.s. \\
\hline informatie- \& communicatietechnologie te gebruiken & 17,6 & 0,719 & 15,9 & 0,663 \\
\hline in buitenlandse talen te communiceren & 7,3 & 0,908 & 14,3 & 0,510 \\
\hline informatie te vergaren & 13,8 & 0,553 & 17,6 & 0,505 \\
\hline problemen en kansen te signaleren & 39,6 & n.s. & 33,2 & 0,690 \\
\hline verbanden te leggen tussen verschillende zaken & 26,0 & 0,614 & 27,3 & 0,662 \\
\hline hoofd- van bijzaken te onderscheiden & 23,3 & 0,606 & 27,5 & n.s. \\
\hline logisch te redeneren & 15,4 & n.s. & 18,3 & 0,531 \\
\hline conform budget, planning of richtlijnen te werken & 18,6 & n.s. & 27,3 & n.s. \\
\hline onder druk goed te functioneren & 31,3 & n.s. & 28,6 & n.s. \\
\hline knopen door te hakken & 26,8 & n.s. & 29,1 & 0,733 \\
\hline nieuwe ideeën en oplossingen te bedenken & 31,5 & n.s. & 28,9 & n.s. \\
\hline nieuwe dingen te leren & 17,0 & 0,616 & 15,3 & 0,634 \\
\hline aan anderen duidelijk te maken wat u bedoelt & 31,9 & n.s. & 33,3 & n.s. \\
\hline productief met anderen samen te werken & 21,1 & 0,543 & 17,4 & 0,664 \\
\hline capaciteiten van anderen aan te spreken & 34,6 & n.s. & 28,3 & n.s. \\
\hline zelfstandig de werkzaamheden uit te voeren & 21,8 & 0,696 & 21,1 & 0,615 \\
\hline \multicolumn{5}{|l|}{ Bereidheid om: } \\
\hline de nek uit te steken & 17,7 & n.s. & 17,2 & n.s. \\
\hline eigen en andermans ideeën ter discussie te stellen & 28,6 & n.s. & 24,1 & 0,702 \\
\hline voor eigen standpunt op te komen & 31,1 & n.s. & 26,5 & 0,690 \\
\hline begrip te tonen voor andere standpunten & 15,2 & n.s. & 15,9 & n.s. \\
\hline
\end{tabular}

* Vereist niveau is hoger dan eigen niveau

Bron: HBO-Monitor 2004-2010

Trends alleen vermeld als die op minstens $5 \%$ niveau significant zijn.

Data voor HBO-totaal hierbij herwogen.

$\mathrm{Na}$ de competentietekorten van HPO'ers vergeleken te hebben met de totale groep HBO'ers, rest nog de vraag welke van deze tekorten groter worden in de tijd. Uit tabel 4.2 blijkt dat er sprake is van een stijgende trend voor 9 van de 23 onderscheiden competenties. Dit betekent dat in het Hoger Pedagogisch Onderwijs bijna 40\% van de competentietekorten de afgelopen jaren groter geworden, oftewel afgestudeerden van het HPO die werkzaam zijn in het kerndomein tussen 2004 en 2010 ervaren in toenemende mate een tekort tussen hun eigen niveau en het voor de functie vereiste niveau. Met name het tekort wat betreft het communiceren in buitenlandse talen stijgt relatief sterk in deze periode. Andere competentietekorten die groter zijn 
geworden voor HPO'ers zijn vooral, kennis van het eigen vakgebied en het gebruik van informatie- en communicatietechnologie. Het competentietekort voor de totale groep HBO'ers in de afgelopen periode is vaker toegenomen (bij I2 van de 23 onderscheiden competenties) dan het geval was voor HPO'ers. De tekorten die het snelst oplopen bij het totale $\mathrm{HBO}$ zijn knopen doorhakken, eigen en andermans ideeën ter discussie stellen, voor het eigen standpunt opkomen, en problemen en kansen signaleren. Het tekort dat jaarlijks het meest oploopt bij afgestudeerden van het HPO ten opzichte van de hele groep HBO-afgestudeerden is het vermogen om te communiceren in buitenlandse talen. Echter bij deze competentie doet het HPO het jaarlijks relatief beter dan het $\mathrm{HBO}$-gemiddelde, tevens is het de competentie met het laagste ervaren tekort bij het HPO.

Als we deze trends vergelijken met de besproken ontwikkelingen in het onderwijs, kunnen we een gedeeltelijke bevestiging zien dat de ontwikkelingen in het werkdomein van HPO'ers wordt weerspiegeld in de competenties waarover ze dienen te beschikken. Docenten in het basis- en voortgezet onderwijs staan aan het begin van de onderwijsketen en het is cruciaal dat zij over voldoende kennis en vaardigheden beschikken om leerlingen uit te dagen hun talenten te benutten (HBO-raad, 20IO). De grootste uitdagingen voor de toekomst liggen, naast het verbeteren van het niveau van afgestudeerden, met name in bepaalde '2 Ist century skills'. Voogt en Pareja Roblin (20IO) beweren dat er een gemeenschappelijke set van kern '2Ist century skills' zijn die nodig zijn in vrijwel alle domeinen, bestaande uit samenwerking, communicatie, ICT kennis, en sociale en/ of culturele skills, kritisch denken en probleemoplossing. Daarnaast wordt ook verwezen naar learning skills, zelfmanagement, planning, flexibiliteit, risicobereidheid, entrepreneurial skills, alsook kernvakken op school (zoals wiskunde, taal en natuurkunde/scheikunde/biologie) en interdisciplinair denken. Dit zijn de skills die volgens velen nodig zijn om adequaat te kunnen functioneren in, en een nuttige bijdrage te leveren aan, de kennis en informatie maatschappij van de $2 \mathrm{I}^{\text {ste }}$ eeuw.

Met name het vereiste competentieniveau van het vermogen om conform budget, planning of richtlijnen te werken, de kennis van andere vakgebieden, het vermogen om informatie- en communicatietechnologie te gebruiken en het vermogen om in buitenlandse talen te communiceren zijn relatief laag, alhoewel de laatste twee genoemde competenties wel een stijgende trend laten zien tussen 2004 en 2010. Daarnaast laten de typische '2Ist century' competenties logisch redeneren en het bedenken van nieuwe ideeën en oplossingen beide een negatieve trend in het vereiste niveau zien, echter de trends in het ervaren tekort met betrekking tot beide competenties zijn niet significant. Met betrekking tot de ervaren competentietekorten scoren met name de kennis van het eigen vakgebied, het vermogen om vakkennis in de praktijk toe te passen en het vermogen om problemen en kansen te signaleren relatief laag. Bovendien nemen de competentietekorten van met name het communiceren in buitenlandse talen, het gebruik van informatie - en communicatietechnologie en de kennis van het eigen vakgebied toe tussen 2004 en 2010. 
Als gekeken wordt naar de jaarlijkse competentietekorten (niet gepresenteerd in dit rapport) in plaats van het gemiddelde tekort over de periode 2004-20IO, valt op dat het competentietekort van het gebruik in ICT en het communiceren in buitenlandse talen vanaf 2004 inderdaad (bijna) ieder jaar gestegen zijn. Ondanks de stijgende trend in het competentietekort van de kennis van het eigen vakgebied fluctueren deze tekorten wat meer van jaar tot jaar, en laat 2010 zelfs (ondanks de significante stijgende trend) het laagste tekort zien sinds 2005. Naast de competentie kennis van het eigen vakgebied, hebben nog I5 andere competenties in 2010 (ondanks de soms significante stijgende trends) het laagste competentietekort sinds 2005. Vier competenties hebben in 2010 zelfs de laagste tekorten sinds 2004, dit zijn de kennis van andere vakgebieden, het werken conform budget, planning of richtlijnen, het bedenken van nieuwe ideeën en oplossingen, het ter discussie stellen van eigen en anders ideeën en het opkomen voor het eigen standpunt.

Het is nog te vroeg om conclusies te trekken, maar uit bovenstaande lijkt het erop dat het ontwikkelen van kennisbases in 2009 om de kwaliteit en het niveau van het onderwijs te verhogen voorzichtig een eerste stap in de juiste richting heeft gezet. De grootste uitdagingen voor de toekomst liggen, naast het verbeteren van het niveau van afgestudeerden, met name in bepaalde '2Ist century skills'. In combinatie met elkaar zorgen verschillende ontwikkelingen zoals de druk op budgetten, de financiële crisis en demografische veranderingen er voor dat het Nederlandse onderwijs succesvol curriculum hervormingen moet doorvoeren, ICT tools moet introduceren in het onderwijs en alle andere uitdagingen moet aangaan met toenemende budgetten die onder druk staan en een tekort aan leraren, met name in de jongere leeftijden die waarschijnlijk het beste uitgerust zijn om met deze veranderingen om te gaan. 


\section{Conclusie}

Uitgaande van ontwikkelingen op de arbeidsmarkt voor afgestudeerden van het HPO is in dit rapport nagegaan welke soort competenties van deze afgestudeerden worden gevraagd en welke gevolgen dit heeft voor de toekomstige inrichting van het HPO. Kijken we naar de huidige arbeidsmarkt, dan zien we dat de meeste afgestudeerden van het HPO emplooi vinden in het onderwijs. De HPO-afgestudeerden worden getypeerd door een hoog aandeel van vrouwen, een grote kans op werk in het kerndomein, veel parttime werk, een goede aansluiting tussen opleiding en werk en een grote tevredenheid met de gekozen opleiding en de huidige baan.

In vergelijking met andere $\mathrm{HBO}$-opleidingen heeft het $\mathrm{HPO}$ de beste arbeidsmarktperspectieven voor schoolverlaters met grote knelpunten in de personeelsvoorziening voor HPO-opgeleiden. Voor de HBO lerarenopleidingen 'natuur en techniek' en 'medisch en verzorging' zijn de arbeidsmarktperspectieven het meest gunstig.

Uit het ROA-onderzoek onder afgestudeerden van het $\mathrm{HBO}$, de HBO-Monitor, blijkt met betrekking tot generieke skills dat het vereiste niveau hoger ligt voor HPO dan voor $\mathrm{HBO}$ als geheel. Ze moeten op een hoger niveau beschikken over vakkennis en over het vermogen om deze in de praktijk toe te passen. Bij HPO-afgestudeerden zien we dat vakkennis niet alleen onverminderd belangrijk blijft, maar nog steeds aan belang wint. Wat het belang van generieke '2 Ist century skills' betreft, zien we bij HPO afgestudeerden een stijgende trend met betrekking tot het belang van ICT. Daarnaast zien we dat het belang van capaciteiten van anderen aan te spreken en het communiceren in buitenlandse talen een stijgende trend vertoont.

Uit de HBO-Monitor komt verder naar voren dat naarmate een competentie belangrijker is, afgestudeerden vaker een tekortschietend niveau hebben. De competentietekorten (zowel met betrekking tot het gemiddelde tekort als met betrekking tot een stijgende trend in het tekort) volgen dus grosso modo het belang die de desbetreffende competenties hebben. Dat wil zeggen dat HPO'ers vooral tekorten ervaren in (de toepassing van) hun vakkennis alsook in '2Ist century skills' zoals problemen en kansen signaleren, omgaan met werkdruk, nieuwe ideeën en oplossingen bedenken, anderen duidelijk maken wat bedoeld wordt en voor het eigen standpunt op te komen. Een toename van tekorten zien we met betrekking tot de kennis van het eigen vakgebied alsook de toepassing van ICT en het vermogen om in buitenlandse talen te communiceren. 
Het ontwikkelen van kennisbases in 2009 om de kwaliteit en het niveau van het onderwijs te verhogen is een eerste stap in de juiste richting. Docenten in het basis- en voortgezet onderwijs staan aan het begin van de onderwijsketen en het is cruciaal dat zij over voldoende kennis en vaardigheden beschikken om leerlingen uit te dagen hun talenten te benutten (HBO-raad, 20IO). Met name de '2Ist century skills' spelen een belangrijke rol en zijn nodig om adequaat te kunnen functioneren in, en een nuttige bijdrage te leveren aan, de kennis en informatie maatschappij van de $2 \mathrm{I}^{\text {ste }}$ eeuw. 


\section{Literatuur}

Allen, J., Velden, van der, R. (2011), Skills for the 21 $1^{\text {st }}$ Century: Implications for Education. Essay for the Kenniskamer of the Ministry of Education, Culture and Science, Researchcentrum voor Onderwijs en Arbeidsmarkt (ROA), Maastricht.

ANP (2012), Leraar voor de klas, HBO-raad, Algemeen Nederlands Persbureau (ANP), 20-01-2012.

CBS (2010), Bevolkingsprognose 2009-2060, Centraal Bureau voor de Statistiek, Den Haag.

ECJRC (2011), The Future of Learning: Preparing for Change, Institute for Prospective Technological Studies, JRC Scientific and Technical Reports, European Commission Joint Research Centre (ECJRS), JRC Publication nr: JRC66836.

HBO-monitor, 2004-2010, uitgevoerd door het ROA in opdracht van de HBO-raad. HBO-raad (2012), Inschrijvingen: absolute aantallen.http://cijfers.hbo-raad.nl/QvAJAXZfc/opendoc.htm?document=2_Inschrijvingen.qvw\&host=Local\&anonymous=true, 05-09-2012.

Kennisnet (2010), Vier in alans Monitor 2010, Ict in het odnerwijs: de stand van zaken, Zoetermeer.

Nationaal Netwerk Bevolkingsdaling, Themagroep Krimp en Onderwijs (2009), 'Krimp en Onderwijs', Den Haag.

Ministerie van Onderwijs, Cultuur en Wetenschap (2011), Hoofdlijnenakkoord OCW - HBOraad, Den Haag: OCW.

OECD (2010), The Nature of Learning: Using Research to Inspire Practice, Organisation for Economic Co-operation and Development (OECD), Paris.

ROA (2011), De arbeidsmarkt naar opleiding en beroep tot 2016, Maastricht: Researchcentrum voor Onderwijs en Arbeidsmarkt.

SBO (2010), Krimp als kans. Leerlingendaling in het primair en voortgezet onderwijs, ResearchNed Nijmegen in opdracht van Sectorbestuur Onderwijsarbeidsmarkt.

Taskforce Onderwijs en Demografische Omslag (2009), Krimppijn. Aanval op de gevolgen van krimp voor het onderwijs, Provincie Limburg.

Voogt, J. \& Pareja Roblin, N. (2010), 21st Century Skills. Discussienota, Twente: Universiteit Twente. 



\section{Bijlage: Kernindicatoren voor HPO Bachelor-opleidingen}

Tabel B1

Vijf kernindicatoren voor HPO Bachelor-opleidingen, 2006-2010

\begin{tabular}{|c|c|c|c|c|c|c|}
\hline HPO Bachelor-opleiding & Werkloosheid & $\begin{array}{r}\text { Werkzaam in } \\
\text { kerndomein } \\
\%\end{array}$ & $\begin{array}{r}\text { gem. Bruto } \\
\text { uurloon } \\
€\end{array}$ & $\begin{array}{r}\text { Spijt } \\
\text { opleiding } \\
\%\end{array}$ & $\begin{array}{r}\text { Tevreden met } \\
\text { functie } \\
\%\end{array}$ & n \\
\hline $\begin{array}{l}\text { 2e gr Nederlandse Gebarentaal/ } \\
\text { Tolkenopleiding }\end{array}$ & 0 & 91,5 & 23,42 & 8,6 & 87,8 & 54 \\
\hline $\begin{array}{l}\text { Docent beeldende kunst en } \\
\text { vormgeving }\end{array}$ & 6,1 & 80,6 & 11,93 & 12,9 & $\mathrm{x}$ & 29 \\
\hline Leraar basis-/speciaal onderwijs & 4,5 & 89,6 & 13,02 & 10,5 & 73,4 & 7019 \\
\hline Leraar exact vak (2e gr) & 0,7 & 90,9 & 15,48 & 17,1 & 74,7 & 270 \\
\hline Leraar lichamelijke opvoeding & 2,6 & 88,4 & 14,69 & 6,6 & 78,9 & 714 \\
\hline Leraar maatschappij vak (2e gr) & 4,1 & 91,8 & 15,83 & 16,4 & 69,2 & 422 \\
\hline Leraar taal (2e gr) & 2,4 & 87,1 & 14,82 & 23,1 & 72 & 320 \\
\hline Totaal HPO Bachelor & 4,1 & 89,5 & 13,55 & 11,3 & 73,6 & 8828 \\
\hline Totaal HBO Bachelor & 4,8 & 70,5 & 13,69 & 19,8 & 67,7 & 70409 \\
\hline
\end{tabular}

$X=$ geen waarnemingen

Opleidingen waarvoor in de periode 2006-2010 in een of meerdere jaren geen gegevens beschikbaar waren, zijn gearceerd.

Bron: HBO-Monitor 2006-2010

\section{Toelichting}

- Werkloosheid: Het werkloosheidspercentage heeft betrekking op de werkloze beroepsbevolking: schoolverlaters zonder werk (of met werk van minder dan 12 uur per week) die op zoek zijn naar betaald werk. Daarbij is tevens als voorwaarde gesteld dat de maatschappelijke positie niet scholier of student is.

- Kerndomein: Het percentage dat aangeeft dat het door de werkgever vereiste opleidingsniveau minimaal HBO is en dat de door de werkgever vereiste opleidingsrichting overeenkomt met of verwant is aan de eigen opleidingsrichting.

- Bruto uurloon: Dit betreft het gemiddelde bruto inkomen in de hoofdfunctie. Dit is inclusief toeslagen maar exclusief inkomen uit overwerk. Er is hier niet gecorrigeerd voor verschillen in leeftijd van de schoolverlaters; wel voor inflatie.

- Spijt opleiding: Het percentage dat aangeeft achteraf gezien voor een andere opleiding op hetzelfde of ander niveau te hebben willen kiezen.

- Tevredenheid: Hoe tevreden bent u met uw huidige functie ( 1 'zeer ontevreden' tot en met 5 'zeer tevreden'. Vermeld is het percentage van antwoordcategorie 4 en 5. 
